\title{
Exposição a agrotóxicos e suas consequências para a saúde humana
}

\author{
Pesticides exposure and consequences to human health \\ Exposición a plaguicidas y sus consecuencias para la salud humana
}

Recebido: 24/06/2021 | Revisado: 30/06/2021 | Aceito: 03/07/2021 | Publicado: 15/07/2021

\author{
Graziela Rodrigues Ródio \\ ORCID: https://orcid.org/0000-0003-4220-1399 \\ Universidade Federal do Paraná, Brasil \\ E-mail: grazielavr@hotmail.com \\ Isac George Rosset \\ ORCID: https://orcid.org/0000-0003-2989-7854 \\ Universidade Federal do Paraná, Brasil \\ E-mail: rosset@ufpr.br \\ Ana Paula Carneiro Brandalize \\ ORCID: https://orcid.org/0000-0002-5293-8186 \\ Universidade Federal do Paraná, Brasil \\ E-mail: anapaulabrandalize@yahoo.com.br
}

\begin{abstract}
Resumo
Desde a chegada das primeiras amostras de agrotóxicos no Brasil a comercialização destes produtos químicos só vem aumentando. Por isso, a população encontra-se exposta a diversas classes de pesticidas por toda a vida. Tendo isso em vista, o presente trabalho objetiva revisar a utilização de agrotóxicos nas culturas brasileiras, bem como demonstrar a importância do conhecimento e conscientização da população acerca das consequências do uso destes produtos para a saúde pública. Para isso, realizou-se o levantamento de dados referente a utilização de defensivos na agricultura e suas consequências à saúde da população, através da utilização de metodologia descritiva-analítica-reflexiva. A exposição constante às diversas classes de agrotóxicos representa grave risco a saúde pública, seja por intoxicações agudas, resultantes da exposição a altas concentrações em um curto período, seja por intoxicações crônicas, decorrentes do contato com baixas concentrações por longos períodos. Muito embora os trabalhadores agrícolas e a população que vive ao redor das culturas sejam mais susceptíveis aos danos causados por estes produtos, as consequências ultrapassam os limites rurais, atingindo toda a população, através da contaminação de alimentos, água e ar contaminado por estes compostos. Conclui-se que é necessária a ampliação de pesquisas na área a fim de se entender as consequências da utilização de agrotóxicos a longo prazo à saúde e ao meio ambiente. É necessário também a adequação das ações fiscalizadoras, a fim de diminuir os danos causados pelo o uso indevido dos produtos, bem como desenvolver ações preventivas e informativas a todos que utilizam-se de defensivos.
\end{abstract}

Palavras-chave: Pesticidas; Intoxicação; Alimentos; Ar; Água; Trabalhadores-rurais; Defensivos-agrícolas.

\begin{abstract}
Since the arrival of the first samples of pesticides in Brazil the tradings of these chemicals has only increased. Therefore, the population is exposed to various classes of pesticides throughout their lives. Considering this the present study aims to review the use of pesticides in brazilian cultures to demonstrate the importance of the population's knowledge and awareness about the consequences of the use of these products for public health. To do so data about the use of pesticides in agriculture and its consequences for the health of the population was collected through the use of descriptiveanalytical-reflective methodology. Constant exposure to the various classes of pesticides represents a serious risk to public health, whether due to acute intoxications resulting from exposure to high concentrations in a short period, or to chronic intoxications resulting from contact with low concentrations for long periods. Even though agricultural workers and the population living around crops are more susceptible to the damage caused by these products, the consequences go beyond rural limits, reaching the entire population through food, water and air contaminated by these compounds. In conclusion it is necessary to increase researchs in this Field in order to understand the long-term consequences of the use of pesticides on health and the environment. It is also necessary to adjust surveillance actions in order to reduce the damage caused by the incorrect use of products as well to develop preventive and informative actions for all who use pesticides.
\end{abstract}

Keywords: Pesticides; Poisoning; Food; Air; Water; Rural-workers.

\section{Resumen}

Desde la llegada de las primeras muestras de plaguicidas a Brasil, la comercialización de estos químicos solo ha aumentado. Por lo tanto, la población está expuesta a diversas clases de pesticidas a lo largo de su vida. Con esto en mente, el presente estudio tiene como objetivo revisar el uso de plaguicidas en las culturas brasileñas, así como demostrar la importancia del conocimiento y la conciencia de la población sobre las consecuencias del uso de estos 
productos para la salud pública. Para ello, se recolectaron datos sobre el uso de plaguicidas en la agricultura y sus consecuencias para la salud de la población, mediante el uso de metodología descriptiva-analítico-reflexiva. La exposición constante a las distintas clases de plaguicidas representa un grave riesgo para la salud pública, ya sea por intoxicaciones agudas, como resultado de la exposición a altas concentraciones en un período corto, o por intoxicaciones crónicas, derivadas del contacto con concentraciones bajas durante períodos prolongados. Si bien los trabajadores agrícolas y la población que vive alrededor de los cultivos son más susceptibles a los daños causados por estos productos, las consecuencias van más allá de los límites rurales, llegando a toda la población, a través de alimentos, agua y aire contaminados por estos compuestos. Se concluye que es necesario ampliar la investigación en el área para comprender las consecuencias a largo plazo del uso de plaguicidas sobre la salud y el medio ambiente. También es necesario adecuar las acciones de inspección con el fin de reducir los daños ocasionados por el uso inadecuado de los productos, así como desarrollar acciones preventivas e informativas para todos los usuarios de plaguicidas.

Palabras clave: Plaguicidas; Intoxicaciones; Alimentos; Aire; Agua; Trabajadores-rurales.

\section{Introdução}

Desde a chegada das primeiras amostras de agrotóxicos no Brasil, na década de quarenta, a comercialização e utilização destes produtos em nosso país têm aumentado. Segundo dados do Censo Agropecuário do ano de 2017, 1.681 .001 produtores rurais utilizaram agrotóxicos em suas culturas, representando um aumento de 20,4\% em comparação aos últimos 11 anos (IBGE, 2018).

De acordo com Carneiro et al. (2015), no ano de 2011, foram pulverizados, em 71 milhões de hectares de lavoura, cerca de 853 milhões de litros de defensivos agrícolas. O disseminado uso destes produtos representa um grave risco à saúde pública, uma vez que, conforme dados relativos ao ano de 2014, foram notificados, em média, 6,26 casos de intoxicações por uso de agrotóxico a cada 100 mil habitantes. Ainda, entre os anos de 2007 a 2015, 84.206 casos foram notificados no Brasil (Brasil, 2018). Apesar dos altos números, este montante não corresponde a real situação, pois estima-se que para cada caso registrado existam outros 50 sem notificação, mesmo sendo um evento de notificação compulsória (Fonseca, 2019).

A permanente exposição a tais defensivos agrícolas está associada a intoxicações. A gravidade destas intoxicações varia em intensidade, dependendo de inúmeros fatores, tais como: absorção do produto, tempo de exposição, toxicidade e o tempo decorrido entre a intoxicação e o atendimento médico (Brasil, 2018). A absorção do agrotóxico pode ocorrer através da pele, mucosas ou vias aéreas (Maia et al., 2018) e a exposição decorre de várias fontes, como alimentos, água, solo e ar contaminados, bem como pelo contato direto com o produto durante o desenvolvimento de atividades laborais no meio rural (Palma, 2011). Os efeitos adversos causados pela exposição aos pesticidas variam de acordo com a gravidade e forma da intoxicação, sendo relacionado às mais diversas patologias que, devido a inespecificidade dos sintomas, muitas vezes deixam de ser efetivamente atribuídas aos agrotóxicos (Pereira, 2019).

Muito embora os trabalhadores agrícolas e a população que vive ao redor das culturas sejam mais susceptíveis aos danos causados por estes produtos, as consequências ultrapassam os limites rurais, atingindo toda a população. Os riscos são exponenciais a determinados grupos, como crianças, mulheres em idade reprodutiva, grávidas, lactantes, idosos e indivíduos com vulnerabilidade biológica e genética (Pereira, 2019).

Tendo em vista o crescente aumento na utilização de pesticidas e consequente exposição a tais substâncias químicas, o presente trabalho objetiva revisar a utilização de agrotóxicos nas culturas brasileiras, bem como demonstrar a importância do conhecimento e conscientização da população acerca das consequências do uso destes produtos para a saúde pública.

\section{Metodologia}

O presente trabalho visa o levantamento de dados referente a utilização de defensivos na agricultura e suas consequências à saúde da população, através da utilização de metodologia descritiva-analítica-reflexiva (Estrela, 2018). 
Foi realizado uma revisão bibliográfica da literatura dos últimos 20 anos, compreendidos entre 2000 a 2020, de artigos científicos, incluindo estudos clínicos e laboratoriais, relatos de caso, revisões, editoriais, cartas, domínios na internet e demais publicações relacionadas ao tema. Para tanto foram utilizadas as bases de dados: PubMed, Scientific Electronic Library Online (Scielo) e ScienceDirect. O Sistema de Informação de Agravos de Notificação - SINAN e demais órgãos relevantes na área em comento, foram consultadas, bem como a legislação pátria vigente, que remonta ao período de 1989 aos dias atuais.

As buscas foram realizadas utilizando as palavras-chaves: agrotóxicos, pesticidas, agroquímicos, toxicidade, carcinógenos, mutagênicos, efeitos adversos, intoxicação ocupacionais, saúde do trabalhador, contaminação ambiental, contaminação alimentar, saúde pública, exposição. Todos os termos foram utilizados nos idiomas português, inglês e espanhol.

Foram incluídos livros, teses, dissertações e outras fontes de informação, em Inglês, Português e Espanhol, públicas e passíveis de obtenção online, dos últimos 20 anos, excetuando-se a legislação, que envolve anos anteriores, todavia ainda vigentes. Todo o material é relacionado a utilização e regulamentação de agrotóxicos nos Brasil, a classificação dos agrotóxicos, dados toxicológicos dos agrotóxicos, consequências a saúde causada pela exposição aos agrotóxicos, intoxicação ocupacional, intoxicação não ocupacional, exposição em gestantes e lactentes, exposição por ingestão de alimentos, exposição por consumo de água e exposição pelo ar.

Para isso, as bibliografias relacionadas à toxicologia in vitro, toxicologia humana/clínica, epidemiologia, desenvolvimento de efeitos e resultados e revisão da exposição humana aos agrotóxicos foram analisados. Já as publicações que abordaram estudos de técnicas laboratoriais, análise/toxicologia em animais e contaminação ambiental, sem relação com efeito para o ser humano, foram excluídas do trabalho.

A categorização dos textos se deu da seguinte maneira:

- Histórico, uso dos agrotóxicos e classificação;

- Consequências a saúde causados pela exposição aos agrotóxicos;

- Tipos de exposição a agrotóxicos.

Foram excluídas das buscas publicações em duplicata, aquelas cujo objetivo era a análise de técnicas de mensuração, as que se relacionavam à avaliação e toxicologia em animais (não humanos), as que avaliavam intoxicações a demais contaminantes, por exemplo, industriais, bem como legiaslações já revogadas. Após exclusão, restaram 96 publicações que contemplavam os critérios estabelecidos para o tema. Das 95 bibliografias, 64 eram artigos científicos relacionados, 13 legislações, 18 artigos e relatórios de órgãos competentes e um site de base de dados.

\section{Desenvolvimento}

\subsection{O Início Da Utilização De Agrotóxicos No Brasil E Sua Regulamentação}

Como sabido, a Revolução Industrial promoveu grande êxodo rural, que, por consequência, trouxe inúmeras modificações na vida da população da época, a destacar melhorias e maior acesso aos serviços de saúde. Tal fato, aliado à evolução da medicina, favoreceu o aumento da perspectiva de vida da população. Por consequência, o crescimento exponencial resultante causou preocupação nas gerações vindouras quanto as limitações de recursos alimentares (Serra et al., 2016).

Diante disto, a humanidade procurou novas técnicas para ampliar sua produção alimentícia e, na década de 1940, surgiu um movimento que visava o aumento da produtibilidade agrícola. Foram aplicadas inovações tecnológicas, desenvolvimento de pesquisas em sementes, fertilização de solos, utilização de agrotóxicos e mecanização agrícola, tendo como argumento exterminar a fome do mundo (Serra et al., 2016).

Neste contexto, ocorreu o aperfeiçoamento, desenvolvimento e produção em larga escala de produtos agrotóxicos (Silva et al., 2005).

O termo agrotóxico assim se define: 
Produtos e agentes de processos físicos, químicos ou biológicos, destinados ao uso nos setores de produção, no armazenamento e beneficiamento de produtos agrícolas, nas pastagens, na proteção de florestas, nativas ou plantadas, e de outros ecossistemas e de ambientes urbanos, hídricos e industriais, cuja finalidade seja alterar a composição da flora ou da fauna, a fim de preservá-las da ação danosa de seres vivos considerados nocivos, bem como as substâncias e produtos empregados como desfolhantes, dessecantes, estimuladores e inibidores de crescimento (Brasil, 2002).

No Brasil, as primeiras amostras de agrotóxicos chegaram ao Instituto Biológico de São Paulo no ano de 1943. Mas, foi durante a década de 60, que estes produtos passaram a participar da rotina dos trabalhadores rurais (Silva et al., 2005). A intensificação de seu uso se deu a partir de 1975, com o Plano Nacional de Desenvolvimento (PND), que, difundiu o uso desses defensivos agrícolas em território nacional, instituiu uma cota definida de agrotóxicos, em troca da obtenção de recursos do crédito rural. Este incentivo, somado a propaganda dos fabricantes, disseminou a utilização de agrotóxicos em solo brasileiro (Silva et al., 2005; Bülow, 2008).

A partir de então os números só vem aumentando. Segundo a ANVISA (2012), do ano de 2002 a 2012 , o mercado nacional de agrotóxicos cresceu $190 \%$, frente a um crescimento mundial de $93 \%$. Ainda, segundo estes dados, no ano de 2008 , o Brasil passou os Estados Unidos da América e assumiu o posto de maior mercado mundial de agrotóxicos. Acrescenta-se, também, que no ano de 2010 o mercado nacional movimentou cerca de U\$ 7,3 bilhões, representando 19\% do mercado global de agrotóxicos. No ano de 2013, foram comercializadas 495,7 mil toneladas de pesticidas, enquanto em 2017 o número chegou a 539,9 mil toneladas. O recorde de comercialização ocorreu em 2016, com 541,8 mil toneladas vendidas (IBAMA, 2018b). Em relação a utilização, dentre os anos 2006 e 2017, houve um aumento de 20,4\% no número produtores que utilizaram agrotóxicos, segundo o Censo Agro de 2017 (IBGE, 2018).

Dito isso, o uso exacerbado e muitas vezes incorreto destes produtos causa riscos de contaminação ambiental e a saúde humana. O comercio e uso destes produtos foram ordenados, implementando-se um conjunto de estratégias para o controle, avaliação, prevenção e gerenciamento dos agrotóxicos, a fim de minimizar os efeitos adversos à saúde. Surge, assim, a Lei Federal $\mathrm{n}^{\circ}$ 7.802, de 11 de julho de 1989, doravante conhecida como Lei dos Agrotóxicos. O referido instrumento legal passou a envolver os Ministérios da Agricultura, Saúde e Meio Ambiente, proporcionando maior proteção ao meio ambiente e aos seres vivos (Bülow, 2008).

Esta lei, posteriormente, em 4 de janeiro de 2002, foi regulamentada pelo Decreto Federal n ${ }^{\circ} 4.074$, que dispõe sobre a pesquisa, a experimentação, a produção, a embalagem e rotulagem, o transporte, o armazenamento, a comercialização, a propaganda comercial, a utilização, a importação, a exportação, o destino final dos resíduos e embalagens, o registro, a classificação, o controle, a inspeção e a fiscalização de agrotóxicos, seus componentes e afins (Silva et al., 2005).

Além disso, outros órgãos também introduziram em nosso ordenamento jurídico normas relativas à utilização dos agrotóxicos, vide a Norma Regulamentadora 31 (NR31) do Ministério do Trabalho e Emprego (MTE), que, dentre outros aspectos, também regulamenta a utilização de agrotóxicos. Segundo este instrumento, seria responsabilidade do MTE fiscalizar os ambientes e as condições de uso destes produtos químicos. Porém, as ações de fiscalização deste órgão possuem baixa eficácia, especialmente devido às limitações metodológicas, materiais e de pessoal (Silva et al., 2005).

Como exposto, nota-se que legislação sobre o tema é complexa e segmentada, sendo complementada por normativas de órgãos de todos os níveis da Administração Pública.

Assim, a nível nacional, existem as Leis Federais n $n^{\circ} 7.802 / 89$ e nº 12.651/12, com critérios de classificação recentemente modificados pela resolução da ANVISA de 2019 (Brasil, 2019a). Ainda, existem as particularidades do Decreto Federal ${ }^{\circ}$ 4.074/02, da Portaria no 86/05 e da Norma Técnica nº 9843/2019 da ABNT.

O Estado do Paraná, em complementação, possui a Lei Estadual no 7.827/83, o Decreto Estadual no $3.876 / 94$ e a Resolução no 57/2014 da Secretaria de Estado de Meio Ambiente e Recursos Hídricos, que estabelece requisitos, condições técnicas e obrigações para o recebimento, manuseio e destino das embalagens vazias de agrotóxicos e outras do meio rural. 
A comercialização do produto no âmbito estadual ainda depende de prestação de informações ao SIAGRO - Sistema de Monitoramento do comércio e Uso de Agrotóxicos do Estado do Paraná, na forma do Decreto Estadual nº 6.107 de 19 de janeiro de 2010.

No mais, o trabalho de fiscalização do comércio e uso de agrotóxicos, receituário agronômico e prestação de serviços fitossanitários está entre as atribuições da Agência de Defesa Agropecuária do Paraná - ADAPAR, criada através da Lei Estadual n 17.026/2011, com atenção e amparo nas Leis Federais, Leis Estaduais e Decretos supracitadas.

\subsection{Classificação Dos Agrotóxicos}

Existem cerca de 300 ingredientes ativos e mais de 2 mil formulações comerciais diferentes no Brasil. Devido a esta grande diversidade de produtos, os agrotóxicos são classificados de diversas formas, sendo as principais quanto a toxicidade, ao tipo de organismo que controlam e ao grupo químico a que pertencem (Batista, 2014).

a- Quanto ao tipo de organismo que controlam: estes podem ser classificados em acaricidas, bactericidas, fungicidas, herbicidas, inseticidas, nematicidas, raticidas, vermífugos, entre outros (Farias, 2017).

b- Quanto ao grupo químico a que pertencem: podem ser classificados em orgânicos, subdivididos em carbamatos (nitrogenados), clorados, fosforados e clorofosforados; inorgânicos, cujas composições químicas apresentam arsênio, tálio, bário, nitrogênio, fósforo, cádmio, ferro, selênio, chumbo, cobre, mercúrio e zinco; e os botânicos, compostos de nicotina, piretrina, sabadina e rotenona (Farias, 2017).

c- Quanto a toxicidade: segundo a Resolução da Agência Nacional de Vigilância Sanitária nº 296, de 29 de julho de 2019, os agrotóxicos podem ser classificados em extremamente tóxico, altamente tóxico, moderadamente tóxico, pouco tóxico, improvável de causar dano agudo e não classificados, segundo os limites demonstrados na Quadro 1. Os efeitos agudos e crônicos dos produtos agrícolas devem ser testados toxicologicamente em animais de laboratório a fim de se obter os seguintes dados: DL50 oral; DL50 cutânea; CL50 inalatória; corrosão/irritação cutânea; corrosão/irritação ocular; sensibilização cutânea; sensibilização respiratória e mutagenicidade (Brasil, 2019a). Esta classificação veio em substituição a Portaria nº 03, de 16 de janeiro de 1992, do Ministério da Saúde, até então vigente, com o intuito de seguir o padrão internacional previsto no Sistema de Classificação Globalmente Unificado (Globally Harmozed System of Classification and Labelling of Chemicals - GHS). 
Quadro 1 - Classificação Toxicológica de Acordo com a Toxicidade Aguda.

\begin{tabular}{|c|c|c|}
\hline Classificação & Categoria de perigo e & o limite \\
\hline \multirow{6}{*}{$\begin{array}{c}\text { EXTREMAMENTE } \\
\text { TÓXICO }\end{array}$} & Oral (mg/kg p.c.) & $\leq 5$ \\
\hline & Cutânea (mg/kg p.c.) & $\leq 50$ \\
\hline & Inalatória & \\
\hline & Gases $(\mathrm{ppm} / \mathrm{V})$ & $\leq 100$ \\
\hline & Vapores (mg/L) & $\leq 0,05$ \\
\hline & Produtos sólidos e líquidos (mg/L) & $\leq 0,05$ \\
\hline \multirow{6}{*}{$\begin{array}{l}\text { ALTAMENTE } \\
\text { TÓXICO }\end{array}$} & Oral (mg/kg p.c.) & $>5-50$ \\
\hline & Cutânea (mg/kg p.c.) & $>50-200$ \\
\hline & Inalatória & \\
\hline & Gases $(\mathrm{ppm} / \mathrm{V})$ & $>100-500$ \\
\hline & Vapores (mg/L) & $>0,5-\leq 2,0$ \\
\hline & Produtos sólidos e líquidos (mg/L) & $>0,05-0,5$ \\
\hline \multirow{6}{*}{$\begin{array}{l}\text { MEDIAMENTE } \\
\text { TÓXICO }\end{array}$} & Oral (mg/kg p.c.) & $>50-300$ \\
\hline & Cutânea (mg/kg p.c.) & $>200-1000$ \\
\hline & Inalatória & \\
\hline & Gases $(\mathrm{ppm} / \mathrm{V})$ & $>500-2500$ \\
\hline & Vapores (mg/L) & $>2,0-\leq 10$ \\
\hline & Produtos sólidos e líquidos (mg/L) & $>0,5-1,0$ \\
\hline \multirow{6}{*}{ POUCO TÓXICO } & Oral (mg/kg p.c.) & $>300-2000$ \\
\hline & Cutânea (mg/kg p.c.) & $>1000-2000$ \\
\hline & Inalatória & \\
\hline & Gases $(\mathrm{ppm} / \mathrm{V})$ & $>2500-20000$ \\
\hline & Vapores (mg/L) & $>10 \leq 20$ \\
\hline & Produtos sólidos e líquidos (mg/L) & $>1,0-5,0$ \\
\hline \multirow{6}{*}{$\begin{array}{c}\text { IMPROVÁVEL DE } \\
\text { CAUSAR DANO } \\
\text { AGUDO }\end{array}$} & Oral (mg/kg p.c.) & $>2000-5000$ \\
\hline & Cutânea (mg/kg p.c.) & $>2000-5000$ \\
\hline & Inalatória & \\
\hline & Gases $(\mathrm{ppm} / \mathrm{V})$ & $>20000$ \\
\hline & Vapores (mg/L) & $>20$ \\
\hline & Produtos sólidos e líquidos (mg/L) & $>5,0$ \\
\hline \multirow{3}{*}{$\begin{array}{c}\text { NÃO } \\
\text { CLASSIFICADO }\end{array}$} & Oral (mg/kg p.c.) & $>2000-5000$ \\
\hline & Cutânea (mg/kg p.c.) & $>2000-5000$ \\
\hline & Inalatória & - \\
\hline
\end{tabular}

Fonte: ANVISA (2019).

A classificação dos agrotóxicos é de grande importância para o diagnóstico e tratamento das intoxicações em humanos (Palmas, 2011). A ANVISA ainda classifica os agrotóxicos de acordo com a toxicidade crônica em duas classes de perigo: a carcinogenicidade (categorias 1A, 1B e 2) e a toxicidade reprodutiva (categorias 1A, 1B, 2 e Categoria Adicional). Em relação a carcinogenicidade, as categorias $1 \mathrm{~A}$ e $1 \mathrm{~B}$ referem-se a produtos que podem provocar câncer e a categoria 2 a agentes suspeitos de provocar câncer. Quanto a toxicidade reprodutiva, as categorias 1A e 1B são descritas como potencialmente prejudicial a fertilidade ou ao feto; a categoria 2, produtos supostamente prejudiciais a fertilidade ou ao feto, enquanto a categoria adicional 
é descrita para efeitos na lactação ou efeitos na via de lactação, são os potencialmente nocivos às crianças alimentadas com o leite materno (Brasil, 2019a).

$\mathrm{Na}$ Quadro 2, encontram-se indicados dados relativos as marcas comerciais dos 10 princípios ativos mais comercializados no Brasil no ano de 2018, segundo dados do IBAMA (2018a). Considerou-se somente as marcas comerciais que possuem autorização de comercialização e uso liberado ou liberado com restrição de uso, conforme regulamentação vigente no Estado do Paraná. Salienta-se que foram indicados produtos já reclassificados de acordo com a portaria em vigência.

Nota-se que 1.942 produtos já foram reclassificados. Desta forma, 2,2\% correspondem ao nível extremamente tóxico, $4 \%$ a altamente tóxico, $7 \%$ a moderadamente tóxico, $30 \%$ a pouco tóxico, $46 \%$ a improvável de causar dano agudo e $8,6 \%$ a produtos não classificados. Além disso, $0,82 \%$ não foram informados e $0,10 \%$ correspondem a produtos cujo processo matriz não foi localizado (ANVISA, 2019). Estima-se que com esta nova classificação o índice de pesticidas classificados como extremamente tóxicos pela Portaria nº 03 de 1992, no Brasil, passou de 34\% para cerca de 14\% (Brasil, 2019b).

Tais informações aumentam a preocupação quanto a saúde pública e coadunam com os números apresentados pela Organização Mundial de Saúde, qual sugere que ocorram cerca de 193 mil mortes por ano devido a exposição a substâncias químicas nocivas (OPAS/OMS, 2018).

O processo produtivo agrícola brasileiro está cada vez mais dependente dos agrotóxicos e fertilizantes químicos, o que gera intenso debate, confrontando-se fatores econômicos, sociais, ideológicos e culturais. Compondo este cenário, têm-se de um lado pessoas e empresas que defendem o desenvolvimento econômico e a necessidade de aumento da produção no combate a fome. Segundo a Organização das Nações Unidas, a população mundial atingirá 7,9 bilhões de pessoas em 2025. De outro lado, compartilha-se a preocupação com a exposição da população em geral a inúmeras fontes de múltiplos produtos químicos, principalmente durante períodos críticos do desenvolvimento, trazendo complicações não totalmente conhecidas (OIT, 2001; Palmas, 2011; Silva et al., 2005). 
Research, Society and Development, v. 10, n. 8, e43010817526, 2021

(CC BY 4.0) | ISSN 2525-3409 | DOI: http://dx.doi.org/10.33448/rsd-v10i8.17526

Quadro 2 - Dados toxicológicos relativos as marcas comerciais dos 10 princípios ativos mais comercializados no Brasil no ano de 2018.

\begin{tabular}{|c|c|c|c|c|c|c|c|c|c|c|}
\hline $\begin{array}{l}\text { Ingredientes } \\
\text { ativos }\end{array}$ & & $\begin{array}{l}\text { Nova Classificação } \\
\text { Toxicológica }\end{array}$ & $\begin{array}{l}\text { Classificação } \\
\text { Toxicológica } \\
\text { para a DL50 } \\
\text { Oral: } \\
\end{array}$ & $\begin{array}{c}\text { Classificação } \\
\text { Toxicológica } \\
\text { para a DL50 } \\
\text { cutânea: } \\
\end{array}$ & $\begin{array}{l}\text { Classificação } \\
\text { Toxicológica } \\
\text { para a CL50 } \\
\text { inalatória: } \\
\end{array}$ & $\begin{array}{l}\text { Categorização: } \\
\text { irritação dérmica }\end{array}$ & $\begin{array}{l}\text { Categorização: } \\
\text { irritação ocular }\end{array}$ & $\begin{array}{l}\text { Categorização: } \\
\text { sensibilização } \\
\text { dérmica }\end{array}$ & $\begin{array}{l}\text { Categorização: } \\
\text { sensibilizção } \\
\text { respiratória }\end{array}$ & $\begin{array}{c}\text { Danos no DNA: } \\
\text { AMES e } \\
\text { Micronúcleo }\end{array}$ \\
\hline $\begin{array}{l}\text { Glifosato e seus } \\
\text { sais }\end{array}$ & $\begin{array}{l}59 \text { marcas de } \\
\text { comercialização e } \\
\text { uso liberado ou } \\
\text { liberado com } \\
\text { restrição de uso no } \\
\text { estado do Paraná. } \\
\\
\text { Destas, } 48 \text { foram } \\
\text { reclassificados, } \\
\text { conforme: }\end{array}$ & $\begin{array}{l}\text { Categoria 4: Produto } \\
\text { Pouco tóxico (10) } \\
\\
\text { Categoria 5: Produto } \\
\text { improvável de causar } \\
\text { dano agudo (33) } \\
\text { Não classificado (05) }\end{array}$ & $\begin{array}{c}\text { Categoria } 4 \text { - } \\
\text { Nocivo se } \\
\text { ingerido (02) } \\
\text { Categoria 5- } \\
\text { Pode ser } \\
\text { perigoso se } \\
\text { ingerido (28) } \\
\text { Não classificado } \\
\text { (18) }\end{array}$ & $\begin{array}{l}\text { Categoria } 5 \text { - Pode } \\
\text { ser perigoso em } \\
\text { contato com a } \\
\text { pele (31) } \\
\text { Não classificado } \\
\text { (17) }\end{array}$ & $\begin{array}{c}\text { Categoria 3 - } \\
\text { Tóxico se } \\
\text { inalado (02) } \\
\text { Categoria 4 - } \\
\text { Nocivo se } \\
\text { inalado (22) } \\
\text { Categoria 5 - } \\
\text { Pode ser } \\
\text { perigoso se } \\
\text { inalado (07) } \\
\text { Não classificado } \\
(09) \\
\text { Não informado } \\
(08)\end{array}$ & $\begin{array}{c}\text { Categoria 2- } \\
\text { Provoca irritação à } \\
\text { pele (01) } \\
\text { Categoria } 3- \\
\text { Provoca moderada } \\
\text { irritação à pele } \\
\text { (03) } \\
\text { Não classificado } \\
(44)\end{array}$ & $\begin{array}{c}\text { Categoria } 1 \text { - } \\
\text { Provoca lesões } \\
\text { oculares graves } \\
(02) \\
\text { Categoria 2- } \\
\text { provoca irritação } \\
\text { ocular grave (06) } \\
\text { Não classificado } \\
(40)\end{array}$ & $\begin{array}{c}\text { Categoria } 1 \text { - Pode } \\
\text { provocar reações } \\
\text { alérgicas na pele } \\
(03) \\
\text { Não classificado } \\
(45)\end{array}$ & $\begin{array}{c}\text { Não classificado } \\
\text { (10) } \\
\text { Não informado } \\
\text { (38) }\end{array}$ & $\begin{array}{c}\text { Micronúcleo } 48 \\
\text { negativos } \\
\text { AMES } \\
\text { 48 negativos }\end{array}$ \\
\hline 2,4-D & $\begin{array}{l}61 \text { marcas de } \\
\text { comercialização e } \\
\text { uso liberado ou } \\
\text { liberado com } \\
\text { restrição de uso no } \\
\text { estado do Paraná. } \\
\\
\text { Destas, } 49 \text { foram } \\
\text { reclassificados, } \\
\text { conforme: }\end{array}$ & $\begin{array}{l}\text { Categoria 2: Produto } \\
\text { Altamente tóxico (02) } \\
\\
\text { Categoria 4: Produto } \\
\text { Pouco tóxico (37) } \\
\text { Categoria 5: Produto } \\
\text { improvável de causar } \\
\text { dano agudo (10) }\end{array}$ & $\begin{array}{c}\text { Categoria } 4 \text { - } \\
\text { Nocivo se } \\
\text { ingerido } \\
\text { (34) } \\
\text { Categoria 5- } \\
\text { Pode ser } \\
\text { perigoso se } \\
\text { ingerido (12) } \\
\text { Não classificado } \\
(03)\end{array}$ & $\begin{array}{l}\text { Categoria } 5 \text { - Pode } \\
\text { ser perigoso em } \\
\text { contato com a } \\
\text { pele (41) } \\
\text { Não classificado } \\
(07) \\
\text { Não informado } \\
\text { pela empresa (01) }\end{array}$ & $\begin{array}{c}\text { Categoria } 4 \text { - } \\
\text { Nocivo se } \\
\text { inalado (18) } \\
\\
\text { Categoria } 5 \text { - } \\
\text { Pode ser } \\
\text { perigoso se } \\
\text { inalado (20) } \\
\text { Não } \\
\text { Classificado } \\
(07) \\
\text { Não informado } \\
\text { pela empresa } \\
(04)\end{array}$ & $\begin{array}{c}\text { Categoria } 2 \text { - } \\
\text { Provoca irritação à } \\
\text { pele (01) } \\
\text { Categoria } 3 \text { - } \\
\text { Provoca moderada } \\
\text { irritação à pele } \\
(09) \\
\\
\text { Não classificado } \\
(38) \\
\text { Não informado } \\
\text { pela empresa (01) }\end{array}$ & $\begin{array}{c}\text { Categoria } 1 \text { - } \\
\text { Provoca lesões } \\
\text { oculares graves } \\
(30) \\
\text { Categoria 2- } \\
\text { provoca irritação } \\
\text { ocular grave (15) } \\
\text { Não Classificado } \\
\text { (04) }\end{array}$ & $\begin{array}{c}\text { Categoria } 1 \text { - Pode } \\
\text { provocar reações } \\
\text { alérgicas na pele } \\
(03) \\
\text { Não classificado } \\
(45) \\
\begin{array}{c}\text { Não informado pela } \\
\text { empresa (01) }\end{array}\end{array}$ & $\begin{array}{c}\text { Não Classificado } \\
(07) \\
\text { Não informado } \\
\text { pela empresa } \\
\quad(42)\end{array}$ & $\begin{array}{c}\text { Micronúcleo } 48 \\
\text { negativos e } 01 \\
\text { não informado } \\
\text { pela empresa } \\
\text { AMES } \\
\text { 49 negativos }\end{array}$ \\
\hline Mancozebe & $\begin{array}{l}43 \text { marcas de } \\
\text { comercialização e } \\
\text { uso liberado ou } \\
\text { liberado com } \\
\text { restrição de uso no } \\
\text { estado do Paraná. }\end{array}$ & $\begin{array}{l}\text { Categoria 4: Produto } \\
\text { Pouco tóxico (03) } \\
\text { Categoria 5: Produto } \\
\text { improvável de causar } \\
\text { dano agudo (30) }\end{array}$ & $\begin{array}{c}\text { Categoria 5- } \\
\text { Pode ser } \\
\text { perigoso se } \\
\text { ingerido (24) } \\
\text { Não classificado } \\
\quad(09)\end{array}$ & $\begin{array}{l}\text { Categoria } 5 \text { - Pode } \\
\text { ser perigoso em } \\
\text { contato com a } \\
\text { pele (26) } \\
\text { Não classificado } \\
(07)\end{array}$ & $\begin{array}{l}\text { Categoria } 3 \text { - } \\
\text { Tóxico se } \\
\text { inalado (01) } \\
\text { Categoria } 4 \text { - } \\
\text { Nocivo se } \\
\text { inalado (06) }\end{array}$ & $\begin{array}{c}\text { Categoria } 2 \text { - } \\
\text { Provoca irritação à } \\
\text { pele (02) } \\
\text { Categoria } 3 \text { - } \\
\text { Provoca moderada } \\
\text { irritação à pele } \\
\text { (04) } \\
\end{array}$ & $\begin{array}{c}\text { Categoria 1- } \\
\text { Provoca lesões } \\
\text { oculares graves } \\
(01) \\
\text { Categoria 2- } \\
\text { provoca irritação } \\
\text { ocular grave (09) }\end{array}$ & $\begin{array}{c}\text { Categoria 1 - Pode } \\
\text { provocar reações } \\
\text { alérgicas na pele } \\
(10) \\
\text { Não classificado } \\
(23)\end{array}$ & $\begin{array}{c}\text { Não Classificado } \\
(08) \\
\\
\text { Não informado } \\
\text { pela empresa } \\
(25)\end{array}$ & $\begin{array}{c}\text { Micronúcleo } 33 \\
\text { negativos } \\
\text { AMES } \\
33 \text { negativos }\end{array}$ \\
\hline
\end{tabular}


Research, Society and Development, v. 10, n. 8, e43010817526, 2021

(CC BY 4.0) | ISSN 2525-3409 | DOI: http://dx.doi.org/10.33448/rsd-v10i8.17526

\begin{tabular}{|c|c|c|c|c|c|c|c|c|c|c|}
\hline & $\begin{array}{l}\text { Destas, } 33 \text { foram } \\
\text { reclassificados, } \\
\text { conforme: }\end{array}$ & & & & $\begin{array}{c}\text { Categoria 5- } \\
\text { Pode ser } \\
\text { perigoso se } \\
\text { inalado (13) } \\
\text { Não } \\
\text { Classificado } \\
\text { (11) } \\
\text { Não informado } \\
\text { pela empresa } \\
\text { (02) } \\
\end{array}$ & $\begin{array}{l}\text { Não classificado } \\
\text { (27) }\end{array}$ & $\begin{array}{l}\text { Não Classificado } \\
\text { (23) }\end{array}$ & & & \\
\hline Atrazina & $\begin{array}{l}34 \text { marcas de } \\
\text { comercialização e } \\
\text { uso liberado ou } \\
\text { liberado com } \\
\text { restrição de uso no } \\
\text { estado do Paraná. } \\
\text { destas, } 24 \text { foram } \\
\text { reclassificados, } \\
\text { conforme: }\end{array}$ & $\begin{array}{l}\text { Categoria 4: Produto } \\
\text { Pouco tóxico (05) } \\
\text { Categoria 5: Produto } \\
\text { improvável de causar } \\
\text { dano agudo (18) } \\
\text { Não classificado (01) }\end{array}$ & $\begin{array}{c}\text { Categoria } 4 \text { - } \\
\text { Nocivo se } \\
\text { ingerido } \\
(05) \\
\text { Categoria 5- } \\
\text { Pode ser } \\
\text { perigoso se } \\
\text { ingerido (16) } \\
\text { Não classificado } \\
(03)\end{array}$ & $\begin{array}{l}\text { Categoria } 5 \text { - Pode } \\
\text { ser perigoso em } \\
\text { contato com a } \\
\text { pele (18) } \\
\text { Não classificado } \\
\quad(06)\end{array}$ & $\begin{array}{c}\text { Categoria 3 - } \\
\text { Tóxico se } \\
\text { inalado (03) } \\
\text { Categoria } 4 \text { - } \\
\text { Nocivo se } \\
\text { inalado (09) } \\
\text { Categoria 5- } \\
\text { Pode ser } \\
\text { perigoso se } \\
\text { inalado (02) } \\
\text { Não } \\
\text { Classificado } \\
\text { (05) } \\
\text { Não informado } \\
\text { pela empresa } \\
\text { (05) }\end{array}$ & $\begin{array}{c}\text { Categoria } 3 \text { - } \\
\text { Provoca moderada } \\
\text { irritação à pele } \\
(01) \\
\text { Não classificado } \\
\text { (23) }\end{array}$ & $\begin{array}{c}\text { Categoria } 2- \\
\text { provoca irritação } \\
\text { ocular grave (01) } \\
\text { Não Classificado } \\
\text { (23) }\end{array}$ & $\begin{array}{c}\text { Categoria } 1 \text { - Pode } \\
\text { provocar reações } \\
\text { alérgicas na pele } \\
(01) \\
\text { Não classificado } \\
(23)\end{array}$ & $\begin{array}{c}\text { Categoria 1 - } \\
\text { Quando inalado } \\
\text { pode provocar } \\
\text { sintomas } \\
\text { alérgicos, de } \\
\text { asma ou } \\
\text { dificuldades } \\
\text { respiratórias (01) } \\
\text { Não Classificado } \\
(03) \\
\text { Não informado } \\
\text { pela empresa } \\
(20)\end{array}$ & $\begin{array}{c}\text { Micronúcleo } 24 \\
\text { negativos } \\
\text { AMES } \\
24 \text { negativos }\end{array}$ \\
\hline Acefato & $\begin{array}{l}17 \text { marcas de } \\
\text { possuem } \\
\text { comercialização e } \\
\text { uso liberado ou } \\
\text { liberado com } \\
\text { restrição de uso no } \\
\text { estado do Paraná. } \\
\text { Destas, } 14 \text { foram } \\
\text { reclassificados, } \\
\text { conforme: }\end{array}$ & $\begin{array}{l}\text { Categoria 2: Produto } \\
\text { Altamente tóxico (01) } \\
\text { Categoria 3: Produto } \\
\text { moderadamente tóxico } \\
\text { (01) } \\
\text { Categoria 4: Produto } \\
\text { Pouco tóxico (09) } \\
\text { Categoria 5: Produto } \\
\text { improvável de causar } \\
\text { dano agudo (03) }\end{array}$ & $\begin{array}{l}\text { Categoria } 4 \text { - } \\
\text { Nocivo se } \\
\text { ingerido (07) } \\
\\
\text { Categoria } 5 \text { - } \\
\text { Pode ser } \\
\text { perigoso se } \\
\text { ingerido (07) }\end{array}$ & $\begin{array}{l}\text { Categoria } 5 \text { - Pode } \\
\text { ser perigoso em } \\
\text { contato com a } \\
\text { pele (13) } \\
\text { Não classificado } \\
(01)\end{array}$ & $\begin{array}{c}\text { Categoria 2- } \\
\text { Fatal se inalado } \\
(01) \\
\text { Categoria 3 - } \\
\text { Tóxico se } \\
\text { inalado (02) } \\
\text { Categoria 4 - } \\
\text { Nocivo se } \\
\text { inalado (03) } \\
\text { Categoria 5 - } \\
\text { Pode ser } \\
\text { perigoso se } \\
\text { inalado (06) }\end{array}$ & $\begin{array}{c}\text { Categoria } 3 \text { - } \\
\text { Provoca moderada } \\
\text { irritação à pele } \\
\text { (03) } \\
\text { Não classificado } \\
\text { (11) }\end{array}$ & $\begin{array}{c}\text { Não classificado } \\
\text { Categoria 1 - } \\
\text { Provoca lesões } \\
\text { oculares graves } \\
(01) \\
\text { Categoria 2-- } \\
\text { provoca irritação } \\
\text { ocular grave (03) } \\
\text { Não Classificado } \\
(10)\end{array}$ & $\begin{array}{c}\text { Categoria } 1 \text { - Pode } \\
\text { provocar reações } \\
\text { alérgicas na pele } \\
(03) \\
\text { Não classificado } \\
\text { (11) }\end{array}$ & $\begin{array}{l}\text { Não Classificado } \\
\qquad(03) \\
\text { Não informado } \\
\text { pela empresa } \\
\quad(11)\end{array}$ & $\begin{array}{c}\text { Micronúcleo } 14 \\
\text { negativos } \\
\text { AMES } \\
14 \text { negativos }\end{array}$ \\
\hline
\end{tabular}


Research, Society and Development, v. 10, n. 8, e43010817526, 2021

(CC BY 4.0) | ISSN 2525-3409 | DOI: http://dx.doi.org/10.33448/rsd-v10i8.17526

\begin{tabular}{|c|c|c|c|c|c|c|c|c|c|c|}
\hline & & & & & $\begin{array}{c}\text { Não } \\
\text { Classificado } \\
(01) \\
\text { Não informado } \\
\text { pela empresa } \\
(01) \\
\end{array}$ & & & & & \\
\hline $\begin{array}{l}\text { Dicloreto de } \\
\text { Paraquate }\end{array}$ & $\begin{array}{l}14 \text { marcas de } \\
\text { comercialização e } \\
\text { uso liberado ou } \\
\text { liberado com } \\
\text { restrição de uso no } \\
\text { estado do Paraná. } \\
\\
\text { Destas, } 13 \text { foram } \\
\text { reclassificados, } \\
\text { conforme: }\end{array}$ & $\begin{array}{l}\text { Categoria 1: Produto } \\
\text { Extremamente Tóxico } \\
\text { (12) } \\
\text { Categoria 2: Produto } \\
\text { Altamente tóxico (01) }\end{array}$ & $\begin{array}{l}\text { Categoria } 4 \text { - } \\
\text { Nocivo se } \\
\text { ingerido (11) } \\
\text { Categoria } 5 \text { - } \\
\text { Pode ser } \\
\text { perigoso se } \\
\text { ingerido (02) }\end{array}$ & $\begin{array}{c}\text { Categoria 3- } \\
\text { Tóxico em } \\
\text { contato com a } \\
\text { pele (01) } \\
\text { Categoria } 5 \text { - Pode } \\
\text { ser perigoso em } \\
\text { contato com a } \\
\text { pele (12) }\end{array}$ & $\begin{array}{c}\text { Categoria 1- } \\
\text { Fatal se inalado } \\
\qquad(12) \\
\text { Categoria 2- } \\
\text { Fatal se inalado } \\
\quad(01)\end{array}$ & $\begin{array}{c}\text { Categoria 1 - } \\
\text { Provoca } \\
\text { queimadura severa } \\
\text { à pele e dano aos } \\
\text { olhos (03) } \\
\text { Categoria 2 - } \\
\text { Provoca irritação à } \\
\text { pele (06) } \\
\text { Categoria } 3 \text { - } \\
\text { Provoca moderada } \\
\text { irritação à pele } \\
(01) \\
\text { Não classificado } \\
(03)\end{array}$ & $\begin{array}{c}\text { Categoria 1 - } \\
\text { Provoca lesões } \\
\text { oculares graves } \\
(09) \\
\text { Categoria 2- } \\
\text { provoca irritação } \\
\text { ocular grave (01) } \\
\text { Não Classificado } \\
(02) \\
\text { Não informado } \\
\text { pela empresa (01) }\end{array}$ & $\begin{array}{l}\text { Não classificado } \\
\text { (13) }\end{array}$ & $\begin{array}{c}\text { Não classificado } \\
(02) \\
\text { Não informado } \\
\text { pela empresa } \\
(11)\end{array}$ & $\begin{array}{c}\text { Micronúcleo } 13 \\
\text { negativos } \\
\text { AMES } \\
13 \text { negativos }\end{array}$ \\
\hline Enxofre & $\begin{array}{l}04 \text { marcas de } \\
\text { comercialização e } \\
\text { uso liberado ou } \\
\text { liberado com } \\
\text { restrição de uso no } \\
\text { estado do Paraná. } \\
\\
\text { Destas, } 04 \text { foram } \\
\text { reclassificados, } \\
\text { conforme: }\end{array}$ & $\begin{array}{l}\text { Categoria 5: Produto } \\
\text { Improvável de Causar } \\
\text { Dano (04) }\end{array}$ & $\begin{array}{c}\text { Categoria } 5 \text { - } \\
\text { Pode ser } \\
\text { perigoso se } \\
\text { ingerido (03) } \\
\text { Não classificado } \\
\text { (031) }\end{array}$ & $\begin{array}{l}\text { Categoria } 5 \text { - Pode } \\
\text { ser perigoso em } \\
\text { contato com a } \\
\text { pele (03) } \\
\text { Não classificado } \\
(01)\end{array}$ & $\begin{array}{c}\text { Categoria 5 - } \\
\text { Pode ser } \\
\text { perigoso se } \\
\text { inalado (03) } \\
\text { Não classificado } \\
\quad(01)\end{array}$ & $\begin{array}{l}\text { Não classificado } \\
(04)\end{array}$ & $\begin{array}{c}\text { Categoria } 2- \\
\text { provoca irritação } \\
\text { ocular grave (01) } \\
\text { Não Classificado } \\
\quad(03)\end{array}$ & $\begin{array}{c}\text { Categoria } 1 \text { - Pode } \\
\text { provocar reações } \\
\text { alérgicas na pele } \\
(02) \\
\text { Não Classificado } \\
(02)\end{array}$ & $\begin{array}{l}\text { Não Classificado } \\
\qquad(02) \\
\\
\text { Não informado } \\
\text { pela empresa } \\
(02)\end{array}$ & $\begin{array}{c}\text { Micronúcleo } 04 \\
\text { negativos } \\
\text { AMES } \\
04 \text { negativos }\end{array}$ \\
\hline Imidacloprido & $\begin{array}{l}31 \text { marcas de } \\
\text { comercialização e } \\
\text { uso liberado ou } \\
\text { liberado com } \\
\text { restrição de uso no } \\
\text { estado do Paraná. } \\
\\
\text { Destas, } 31 \text { foram } \\
\text { reclassificados, } \\
\text { conforme: }\end{array}$ & $\begin{array}{l}\text { Categoria 3: Produto } \\
\text { moderadamente tóxico } \\
\qquad(02) \\
\text { Categoria 4: Produto } \\
\text { Pouco tóxico (23) } \\
\text { Categoria 5: Produto } \\
\text { improvável de causar } \\
\text { dano agudo (06) }\end{array}$ & $\begin{array}{l}\text { Categoria 3- } \\
\text { Tóxico se } \\
\text { ingerido (02) } \\
\text { Categoria } 4 \text { - } \\
\text { Nocivo se } \\
\text { ingerido (23) } \\
\text { Categoria } 5 \text { - } \\
\text { Pode ser } \\
\text { perigoso se } \\
\text { ingerido (06) }\end{array}$ & $\begin{array}{c}\text { Categoria } 4- \\
\text { Nocivo em } \\
\text { contato com a } \\
\text { pele (01) } \\
\text { Categoria } 5 \text { - Pode } \\
\text { ser perigoso em } \\
\text { contato com a } \\
\text { pele (24) } \\
\text { Não } \\
\text { classificado(06) }\end{array}$ & $\begin{array}{c}\text { Categoria } 3 \text { - } \\
\text { Tóxico se } \\
\text { inalado (05) } \\
\text { Categoria } 4 \text { - } \\
\text { Nocivo se } \\
\text { inalado (08) } \\
\text { Categoria } 5 \text { - } \\
\text { Pode ser } \\
\text { perigoso se } \\
\text { inalado (05) }\end{array}$ & $\begin{array}{l}\text { Não classificado } \\
(31)\end{array}$ & $\begin{array}{l}\text { Não classificado } \\
\text { (31) }\end{array}$ & $\begin{array}{c}\text { Categoria } 1 \text { - Pode } \\
\text { provocar reações } \\
\text { alérgicas na pele } \\
(01) \\
\text { Não Classificado } \\
\text { (30) }\end{array}$ & $\begin{array}{c}\text { Não Classificado } \\
(05) \\
\text { Não informado } \\
\text { pela empresa } \\
(26)\end{array}$ & $\begin{array}{c}\text { Micronúcleo } 31 \\
\text { negativos } \\
\text { AMES } \\
31 \text { negativos }\end{array}$ \\
\hline
\end{tabular}


Research, Society and Development, v. 10, n. 8, e43010817526, 2021

(CC BY 4.0) | ISSN 2525-3409 | DOI: http://dx.doi.org/10.33448/rsd-v10i8.17526

\begin{tabular}{|c|c|c|c|c|c|c|c|c|c|c|}
\hline & & & & & $\begin{array}{c}\text { Não } \\
\text { Classificado } \\
(05) \\
\text { Não informado } \\
\text { pela empresa } \\
(08) \\
\end{array}$ & & & & & \\
\hline Óleo mineral & $\begin{array}{l}04 \text { marcas de } \\
\text { comercialização e } \\
\text { uso liberado ou } \\
\text { liberado com } \\
\text { restrição de uso no } \\
\text { estado do Paraná. } \\
\\
\text { Destas, } 04 \text { foram } \\
\text { reclassificados, } \\
\text { conforme: }\end{array}$ & $\begin{array}{l}\text { Categoria 5: Produto } \\
\text { Improvável de Causar } \\
\text { Dano (03) } \\
\text { Não classificado (01) }\end{array}$ & $\begin{array}{c}\text { Categoria 5- } \\
\text { Pode ser } \\
\text { perigoso se } \\
\text { ingerido (02) } \\
\text { Não classificado } \\
\quad(02)\end{array}$ & $\begin{array}{l}\text { Categoria } 5 \text { - Pode } \\
\text { ser perigoso em } \\
\text { contato com a } \\
\text { pele (01) } \\
\text { Não classificado } \\
(02) \\
\text { Não informado } \\
\text { pela empresa }(01)\end{array}$ & $\begin{array}{c}\text { Não classificado } \\
\qquad(01) \\
\text { Não informado } \\
\text { pela empresa } \\
(03)\end{array}$ & $\begin{array}{c}\text { Categoria } 2 \text { - } \\
\text { Provoca irritação à } \\
\text { pele }(01) \\
\text { Não classificado } \\
(02) \\
\text { Não informado } \\
\text { pela empresa (01) }\end{array}$ & $\begin{array}{c}\text { Categoria } 2- \\
\text { provoca irritação } \\
\text { ocular grave (01) } \\
\begin{array}{c}\text { Não Classificado } \\
(02)\end{array} \\
\text { Não informado } \\
\text { pela empresa (01) }\end{array}$ & $\begin{array}{l}\text { Não Classificado } \\
\quad(02) \\
\text { Não informado pela } \\
\text { empresa (02) }\end{array}$ & $\begin{array}{c}\text { Não Classificado } \\
(01) \\
\text { Não informado } \\
\text { pela empresa } \\
(03)\end{array}$ & $\begin{array}{c}\text { Micronúcleo } 02 \\
\text { negativos e } 02 \\
\text { não informados } \\
\\
\text { AMES } \\
02 \text { negativos e } \\
\text { 02 não } \\
\text { informados }\end{array}$ \\
\hline $\begin{array}{l}\text { Oxicloreto de } \\
\text { cobre }\end{array}$ & $\begin{array}{l}18 \text { marcas de } \\
\text { comercialização e } \\
\text { uso liberado ou } \\
\text { liberado com } \\
\text { restrição de uso no } \\
\text { estado do Paraná. } \\
\\
\text { Destas, } 12 \text { foram } \\
\text { reclassificados, } \\
\text { conforme: }\end{array}$ & $\begin{array}{l}\text { Categoria 4: Produto } \\
\text { Pouco tóxico (07) } \\
\text { Categoria 5: Produto } \\
\text { improvável de causar } \\
\text { dano agudo (05) }\end{array}$ & $\begin{array}{c}\text { Categoria } 4 \text { - } \\
\text { Nocivo se } \\
\text { ingerido (05) } \\
\\
\text { Categoria } 5 \text { - } \\
\text { Pode ser } \\
\text { perigoso se } \\
\text { ingerido (07) }\end{array}$ & $\begin{array}{l}\text { Categoria } 5 \text { - Pode } \\
\text { ser perigoso em } \\
\text { contato com a } \\
\text { pele (12) }\end{array}$ & $\begin{array}{c}\text { Categoria } 4 \text { - } \\
\text { Nocivo se } \\
\text { inalado (02) } \\
\text { Categoria 5- } \\
\text { Pode ser } \\
\text { perigoso se } \\
\text { inalado (06) } \\
\text { Não } \\
\text { Classificado } \\
\text { (02) } \\
\text { Não informado } \\
\text { pela empresa } \\
(02)\end{array}$ & $\begin{array}{c}\text { Categoria } 2 \text { - } \\
\text { Provoca irritação à } \\
\text { pele (01) } \\
\text { Não classificado } \\
\text { (11) }\end{array}$ & $\begin{array}{c}\text { Categoria 1 - } \\
\text { Provoca lesões } \\
\text { oculares graves } \\
(01) \\
\text { Categoria 2- } \\
\text { provoca irritação } \\
\text { ocular grave (06) } \\
\text { Não Classificado } \\
(05)\end{array}$ & $\begin{array}{l}\text { Não Classificado } \\
\text { (12) }\end{array}$ & $\begin{array}{c}\text { Não Classificado } \\
(03) \\
\text { Não informado } \\
\text { pela empresa } \\
(09)\end{array}$ & $\begin{array}{c}\text { Micronúcleo } 11 \\
\text { negativos e 01 } \\
\text { não informados } \\
\\
\text { AMES } \\
11 \text { negativos e } \\
\text { 01 não } \\
\text { informados }\end{array}$ \\
\hline
\end{tabular}

Fontes: IBAMA (2018a); ADAPAR (2019); ANVISA (2019). 


\subsection{Consequências a saúde causadas pela exposição aos agrotóxicos}

\subsubsection{Sintomatologia Das Infecções Por Agrotóxicos}

Como indicado, a exposição constante às diversas classes de agrotóxicos representa grave risco a saúde pública, seja por intoxicações agudas, resultantes da exposição a altas concentrações em um curto período, seja por intoxicações crônicas, decorrentes do contato com baixas concentrações por longos períodos (Silva et al., 2005).

A absorção do agrotóxico pode ocorrer através da pele, mucosas ou vias aéreas. Sua intensidade pode ser influenciada por características pessoais, tais como tabagismo, alcoolismo, estado nutricional e esforço físico; e características climáticas, como temperaturas elevadas, que aumentam a volatilidade e pressão dos vapores químicos e a velocidade da circulação sanguínea (Silva et al. 2005; Maia et al., 2018).

A sintomatologia da intoxicação aguda é nítida e surge algumas horas após a exposição excessiva a produtos altamente tóxicos, variando em intensidade. Pode apresentar-se através de náusea, vômito, cefaléia, tontura, desorientação, hiperexcitabilidade, parestesias, irritação cutânea e mucosa, fasciculação muscular, dificuldade respiratória, hemorragia e convulsões, podendo, inclusive, levar a morte (Silva et al., 2005).

Em estudo realizado nos municípios que compõem a Zona da Mata de Rondônia, foram analisados 40 trabalhadores rurais que atuavam na agricultura familiar ou agroecológica. Em média, 70\% dos entrevistados relataram sintomas agudos como dor de cabeça, tontura, ânsia de vômito, irritação na pele e nos olhos. Ainda, segundo o trabalho, outros sintomas também presentes na intoxicação aguda como irritabilidade, dores abdominais, tensão muscular, imunidade baixa, nervosismo, diarreia e tosse não foram percebidos pela maioria dos trabalhadores como sintomas causados pelos agrotóxicos, especialmente em razão da similaridade da sintomatologia a outras patologias comuns em áreas rurais, como parasitoses do sistema digestivo, disenteria e viroses (Stachiw, 2019).

Ainda, em pesquisa realizada com trabalhadores de três áreas rurais da Inglaterra e País de Gales, a utilização de pesticidas foi vinculada a ocorrência de doze sintomas dentro de 48 horas após o uso, sendo eles: coriza, cefaleia, dor nos membros, febre e calafrios, vertigem, inquietação e ansiedade, dificuldade de concentração, dificuldade de respirar, diarreia, visão desfocada, fraqueza muscular, dormência ou formigamento em mãos e pé. Destes, os sintomas mais frequentemente descritos foram dor de cabeça, dores nos membros, coriza e dores musculares (Solomon et al, 2007).

Por outro lado, as consequências da intoxicação crônica podem surgir após meses ou anos de exposição, ocasionando danos muitas vezes irreversíveis, podendo apresentar-se através de alterações imunológicas, genéticas e endócrinas, com malformações congênitas, câncer, reações alérgicas, alterações comportamentais e efeitos deletérios sobre os sistemas nervoso, hematopoético, respiratório, cardiovascular, geniturinário, trato gastrintestinal, hepático, reprodutivo e endócrino (Silva et al., 2005).

Os diversos efeitos crônicos são desencadeados por agentes químicos que influenciam: fatores genéticos, como formação de micronúcleos, degradação, oxidação e mutação do material genético; fatores imunológicos, como alterações da microbiota intestinal, da citosina IFN- $\gamma$ e da produção de IL-2; fatores endócrinos, como a interrupção dos hormônios sexuais. Ademais, são apontados como causadores de estresse oxidativo (Zhang et al., 2019). Ainda, neste mesmo sentido, os agrotóxicos podem exercer efeitos epigenéticos via metilação do DNA e modificações de histonas, mudanças epigenômicas que serão expressas em disfunções do metabolismo (Fonseca, 2019).

Devido a inespecificidade dos sinais e sintomas, bem como o longo lapso temporal entre a exposição ao produto e as consequentes manifestações, pouco se sabe sobre os reais danos a saúde causados pelas intoxicações crônicas relacionadas a grande variedade de compostos químicos utilizados na agricultura. Diante disto, diversos trabalhos visam entender de que forma a utilização destes produtos interferem na saúde da população a longo prazo (Silva et al., 2005). 
Salienta-se ainda, que a exposição a múltiplos produtos químicos podem potencializar o efeito. Por isso, torna-se necessário a contabilização de exposições múltiplas, bem como exposições que ocorrem durante períodos sensíveis de desenvolvimento, a fim de melhorar a avaliação dos riscos químicos em toda a população (Spivey, 2011).

Segundo o Sistema de Informação de Agravos de Notificação - SINAN, do ano de 2010 a 2020, no Brasil, foram notificados 46.992 casos de intoxicação por agrotóxicos agrícolas. Dentre as notificações, quase a totalidade (89\%), referem-se à infecções agudas. O baixo número de notificações crônicas certamente está relacionado aos motivos já citados anteriormente, que são falta de sinais e sintomas específicos, bem como a não associação aos efeitos tardios, como tumores e distúrbios sistêmicos (Silva et al., 2005). Isto, certamente, dificulta a caracterização epidemiológica e o desenvolvimento de ações preventivas (Meirelles, Veiga \& Duarte, 2016).

Quadro 3 - Sinais e Sintomas relacionados a Intoxicações Agudas e Crônicas por agrotóxicos.

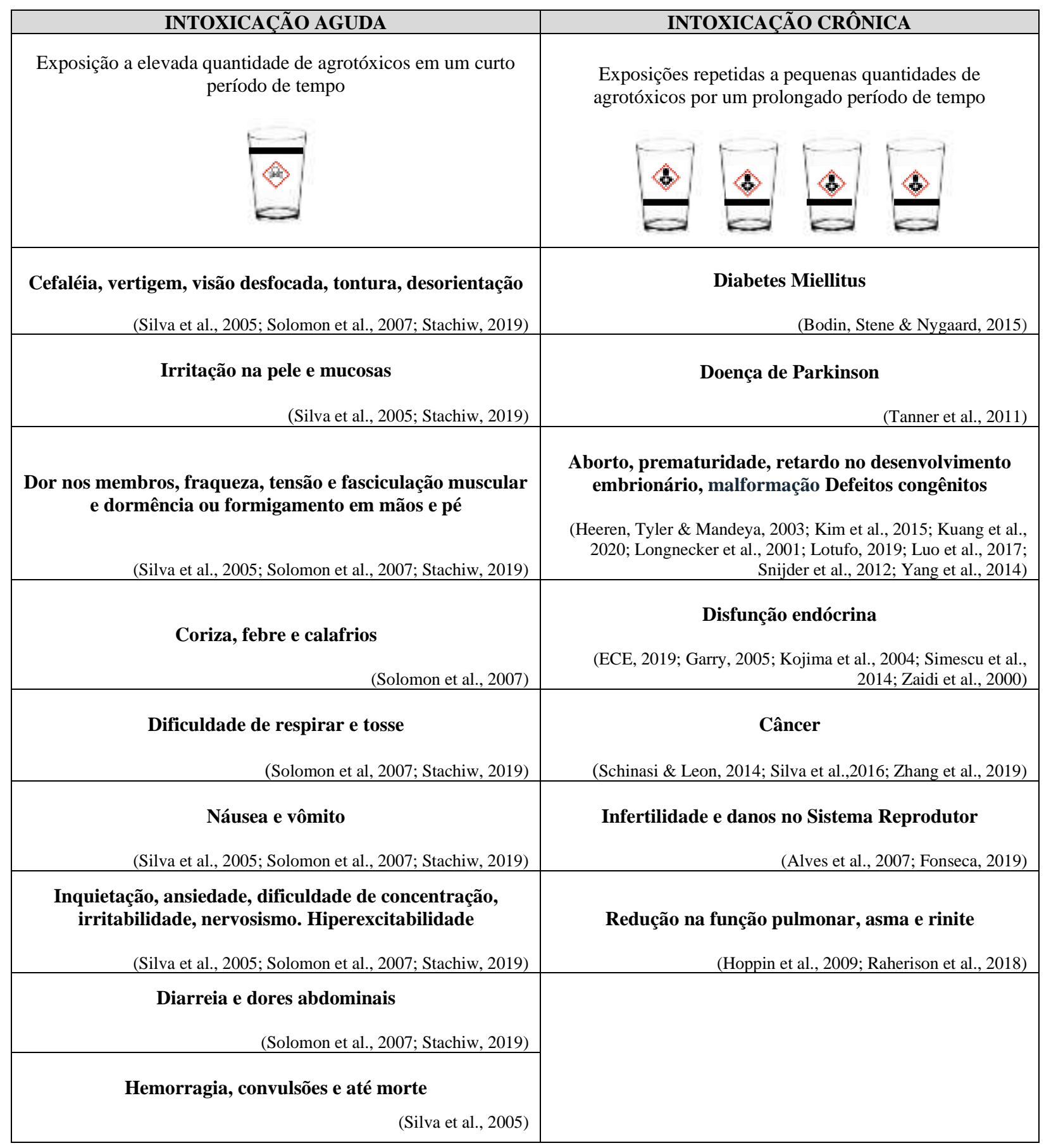


Fonte: Autores.

\subsubsection{Intoxicação ocupacional}

O risco ocupacional refere-se à possibilidade do trabalhador sofrer danos à sua saúde, física ou mental, durante o desenvolvimento de suas atividades laborais. Os agrotóxicos representam um forte risco a saúde dos trabalhadores rurais, sendo esses os mais afetados, já que estão expostos diretamente a estes produtos ao longo de suas jornadas de trabalho (Maia et al., 2018).

Segundo o Sistema de Informações Tóxico Farmacológicas - SINAN, do ano de 2010 a 2020, foram notificados 19.604 casos de intoxicação ocupacional por agrotóxico no Brasil. Apesar da alta incidência, os dados oficiais brasileiros não retratam com exatidão a gravidade de nossa realidade. Diagnósticos incorretos, em conjunto com a falta de notificação por parte dos profissionais da saúde, dificuldade de acesso dos trabalhadores rurais às unidades de saúde, a escassez de laboratórios de monitoramento biológico e a inexistência de biomarcadores precoces e/ou confiáveis, bem como, a falta de padronização de plataforma para notificação torna difícil definir, de forma fidedigna, o número de intoxicações agudas e crônicas causadas por agrotóxicos nos trabalhadores (Silva et al., 2005; Maia et al., 2018).

Tal constatação encontra amparo nos números divulgados no Plano de Vigilância e Atenção à Saúde de Populações Expostas aos Agrotóxicos do Estado do Paraná 2017 a 2019, relativo unicamente ao Estado do Paraná, que do ano de 2012 a 2016 contabilizou 1.530 casos notificados de intoxicações por agrotóxicos relacionados ao trabalho (Paraná, 2017).

Inúmeros trabalhos demonstram intoxicações ocupacionais devido a utilização de defensivos agrícolas por todo o Brasil. Um estudo avaliou dados cadastrais de 382 trabalhadores assistidos no Ambulatório de Toxicologia Ocupacional do Centro de Referência em Saúde do Trabalhador Distrito Federal, entre 2009 e 2013. Destes, 60\% correspondiam a agricultores e agentes de monitoramento ambiental expostos a pesticidas. Ainda, os trabalhadores expostos a agrotóxicos estiveram envolvidos em atividades diversas, incluindo carga, descarga e comercialização de produtos, preparo e aplicação (atividades agropecuárias, campanhas de saúde pública e desinsetizadores) e manutenção de áreas verdes e jardins. Todos relataram exposição a mais de um produto agrotóxico, mas 23,6\% deles não identificaram o grupo químico ou o nome do produto envolvido. Entre os 184 casos com exposição a agrotóxicos com o grupo químico identificado, mais da metade teve o envolvimento de inseticidas organofosforados, principalmente o temefós para agentes de vigilância ambiental e o metamidofós para agricultores. Vinte e um casos envolveram os inseticidas piretroides, dos quais 17 com deltametrina, única ou associada com glifosato, que esteve envolvido em outros 22 casos, sendo 19 com trabalhadores rurais. O inseticida diflubenzuron esteve envolvido em 9 casos com agentes de vigilância. Outros agrotóxicos incluem o inseticida clofenapir e o herbicida paraquate, além de outros 15 agrotóxicos de várias classes (Magalhães \& Caldas, 2019).

Silva et al., (2019), no estado do Mato Grosso, observaram que trabalhadores do setor da Agricultura e de ocupações afins apresentaram 2,52 vezes maior ocorrência de intoxicações agudas quando comparados aos trabalhadores de outras ocupações. No mesmo sentido, morar nas proximidades (a menos de 500 metros) de lavouras (RP=2,39 - IC95\% 1,61;3,53) e trabalhar na zona rural ( $\mathrm{RP}=2,35$ - IC95\% 1,67;3,31) também foram situações associadas a maiores prevalências de intoxicação aguda.

Segundo Faria et al. (2004), nos municípios de Antônio Prado e Ipê, na Serra Gaúcha, 2,0\% dos 1.105 agricultores entrevistados que trabalhavam com agrotóxicos tiveram intoxicações por estes produtos, sendo $20 \%$ destes casos considerados graves.

Em pesquisa realizada entre os anos de 2002 a 2011, no Centro de Controle de Intoxicação de Maringá, localizado no Hospital Universitário Regional de Maringá, do Estado do Paraná, foram encontrados um total de 397 casos de pacientes intoxicados por circunstâncias ocupacionais. Os autores destacam que os meses com maiores incidências de intoxicações foram 
janeiro, fevereiro, março e dezembro. Este período está diretamente relacionado a aplicação de agrotóxico no calendário agrícola da cana de açúcar, da soja e do milho. Levando em consideração o agente envolvido na intoxicação, observa-se que o inseticida foi o provocador de $62,60 \%$ das intoxicações e os herbicidas de $26 \%$. Esta predominância se dá pela grande utilização de inseticidas na agricultura e, também, por ser um agente muito bem absorvido pela pele e por ingestão (Neves \& Bellini, 2013).

Questionários aplicados a 186 trabalhadores rurais, de seis propriedades, localizadas em duas regiões produtoras de tomates do agreste pernambucano, revelaram que do total 13,2\% já sofreram algum tipo de intoxicação, sendo que a maioria necessitou de socorro médico. Destes, 45 relataram mal-estar durante a aplicação do produto; 70,6\% das mulheres entrevistadas relataram perda de feto e 39,4\% revelaram ter perdido um filho com menos de um ano de vida. Identificou0se frequente $(36,4 \%)$ as queixas relacionadas ao sistema imunológico, como febre reiterada e prurido na pele, olhos e nariz; o sintoma relacionado com o sistema osteomuscular de maior ocorrência foi o de dor nas articulações $(35,8 \%)$, enquanto os sistemas nervoso central e periférico foram responsáveis por 32,5\% das queixas, sendo as mais citadas tontura, formigamento nos membros superiores, alterações de sono e vômitos (Araujo, Nogueira \& Augusto, 2000).

Os trabalhos supracitados demonstram o alto número de intoxicações de trabalhadores da agroindústria por agrotóxicos, consequência da alta exposição durante o manuseio, através da manipulação, diluição e preparação das misturas, bem como no decorrer da aplicação, pela dispersão das partículas e durante a colheita. Ainda, notou-se o contato com o produto fora da atividade laboral, como no consumo de alimentos contaminados por agrotóxicos (Maia et al., 2018).

Trabalhadores rurais do sexo masculino são os mais afetados pela exposição ocupacional a agrotóxicos. Segundo o Censo Agro de 2017, apesar do número de produtoras do sexo feminino ter crescido nos últimos anos, o sexo masculino representa 81,4\% dos trabalhadores rurais (IBGE, 2018). Ademais, desenvolvem com mais frequência funções onde o contado com o produto é maior (Maia et al., 2018). Diversos trabalhos demonstram a superioridade de intoxicação no sexo masculino, vide Maia et al. (2018), que observaram no Estado de Alagoas, nos anos de 2010 a 2015, uma prevalência quase absoluta do sexo masculino, representando, na maioria dos anos, $100 \%$ dos casos de intoxicados. Bulow (2008), por sua vez, observou que no ano de 2003, 73,6\% dos óbitos por intoxicação registrados era da população masculina. Rebelo et al. (2011) também verificou prevalência de intoxicações por agrotóxicos em homens, no Distrito Federal, de 2004 a 2007, apesar da menor discrepância entre os sexos, sendo que, dos 709 casos de intoxicações notificadas, 51,2\% eram do sexo masculino. No Paraná, do montante de intoxicações notificados entre os anos de 2012 e 2016, houve prevalência do sexo masculino, com 66\% dos casos e as mulheres representam 34\% dos casos notificados (Paraná, 2017). Ainda no estado do Paraná, mesorregião Geográfica Norte Central Paranaense, encontrou-se que 357 (89,92\%) são homens e apenas 40 (10,08\%) mulheres, do total de 397 pacientes intoxicados por circunstância ocupacional. De acordo com os autores, tal fato está intrinsicamente ligado à predominância do sexo masculino no trabalho no campo (Paraná, 2017).

Em relação a faixa etária, a compreendida entre os 20 aos 49 anos é a mais acometida por intoxicações decorrentes de defensivos agrícolas (Bulow, 2008; Paraná, 2017; Maia et al., 2018). Segundo dados obtidos no SINAN, no ano de 2017, 43,8\% dos casos de intoxicação por agrotóxico agrícola ocorreram em pessoas de 20 a 39 anos. O maior acometimento desta faixa de idade está ligado ao desenvolvimento de atividades que expõem o profissional diretamente ao produto químico, como pulverização e operação de maquinário (Maia et al., 2018).

Segundo dados do IBGE (2018), cerca de 15,5\% dos produtores rurais nunca frequentaram a escola e 79,1\% não foram além do nível fundamental. Este é um dado alarmante quando levamos em conta a segurança do trabalhador, pois implica diretamente no aumento de acidentes laborais. A baixa escolaridade reflete no grau de entendimento do agricultor quanto ao respeito às informações de utilização correta, composição, efeitos adversos e formas de minimizar riscos, todas contidas nos rótulos dos produtos. Muitas vezes, tais informações pautam-se em termos técnicos, o que, na maioria das vezes, dificulta a compreensão (Martins et al., 2012). 
Em seu trabalho, Maia et al. (2018) demostram que 42,69\% dos trabalhadores agropecuários intoxicados por agrotóxico agrícola, em Alagoas, no período de 2010 a 2015, não eram alfabetizados ou possuíam estudos apenas até a $4^{\circ}$ série. Salienta-se que este número pode ser ainda maior, visto que 19,45\% do montante total de intoxicados não tiveram sua escolaridade informada. Ainda, Magalhães e Caldas (2019) identificaram que 46,5\% dos agricultores expostos ocupacionalmente a produtos químicos, atendidos no Ambulatório de Toxicologia Ocupacional do Centro de Referência em Saúde do Trabalhador do Distrito Federal, entre 2009 e 2013, possuía apenas ensino fundamental. No mesmo sentido, no Município de Camocim de São Félix, Pernambuco, dos trabalhadores rurais entrevistados, $41 \%$ eram analfabetos e $41 \%$ possuíam o primário incompleto (Araujo, Nogueira \& Augusto, 2000). A baixa escolaridade impede a leitura eficiente das instruções de uso disposto nas embalagens, resultando no uso incorreto do produto, aumentando assim o risco a saúde do trabalhador, população e meio ambiente (Bulow, 2008).

Ademais, neste mesmo sentido, já foi relatado que grande parte dos produtores possuem pouco conhecimento acerca das especificações contidas nos rótulos dos agrotóxicos. No mais, a dosagem destes produtos é determinada pelos próprios trabalhadores em correspondência ao tempo de cultivo, não se atentando as especificações dos comerciantes e ou vendedores (bulow, 2008).

Em consonância aos trabalhos supracitados, no Gráfico 1, encontra-se dados referentes as variáveis sexo, idade e escolaridade de intoxicações ocupacionais por defensivos agrícolas, segundo dados do SINAN, dos anos de 2010 a 2020. Ressalta-se que quanto a totalidade dos 19.606 casos constantes no sistema, o gráfico escolaridade possui 5.569 casos não indicados, vez que com as variantes Ign/Branco ou não se aplica.

Gráfico 1 - Notificações por sexo, faixa etária e escolaridade de intoxicações por exposição de trabalho à agrotóxicos agrícolas, do período de 2010 a 2020.

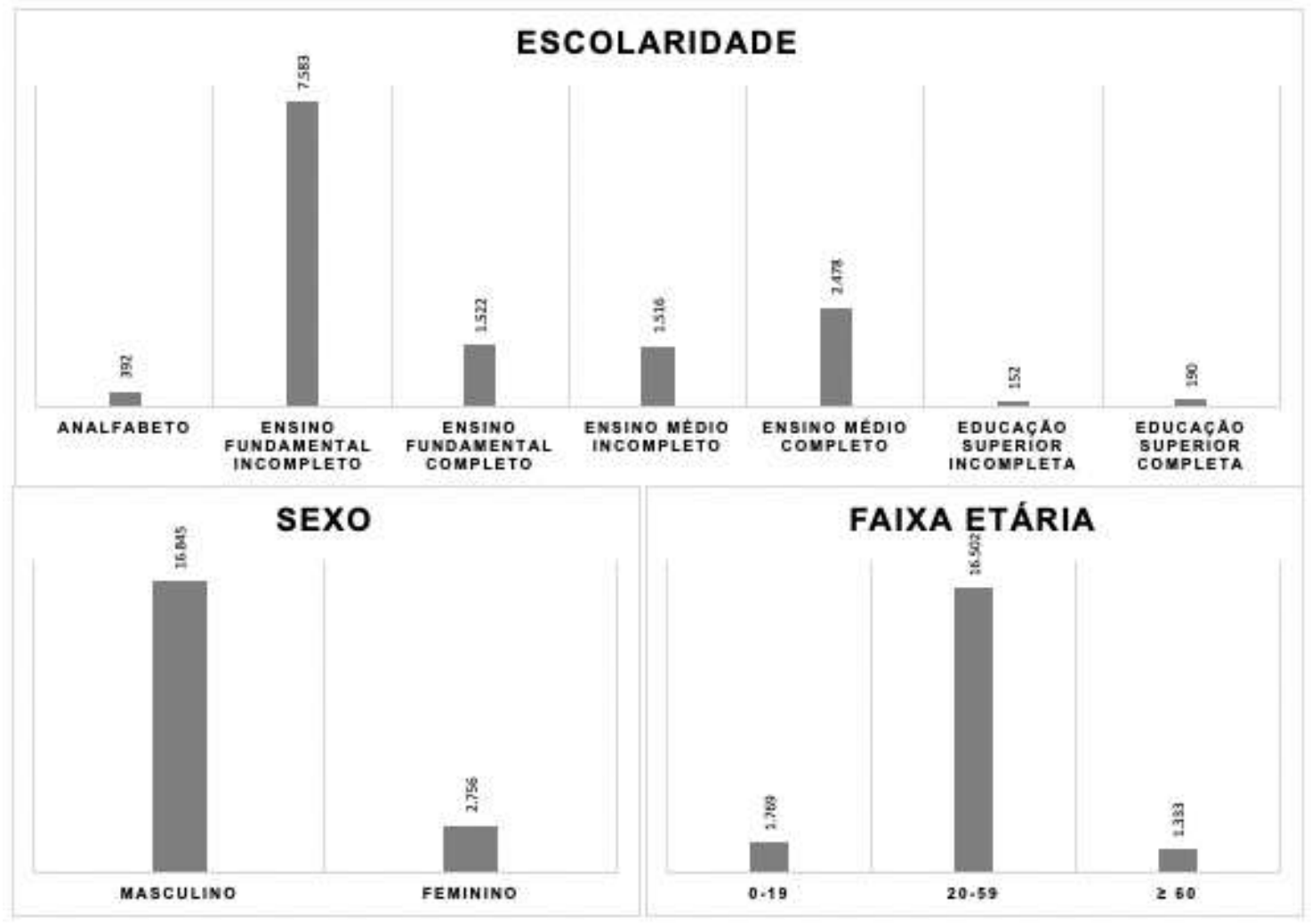

Fonte: Ministério da Saúde/SVS - Sistema de Informação de Agravos de Notificação - Sinan Net. 
Um ponto que pode influenciar na exposição ocupacional aos agrotóxicos é a utilização dos Equipamentos de Proteção Individual (EPI), sendo apontados como uma proteção à saúde e à segurança dos trabalhadores. Entretanto, grande parte dos profissionais não se utilizam destes equipamentos, relatando desconforto físico e térmico na utilização, tornando-os impróprios para o regular desenvolvimento das atividades. No mais, os que utilizam, relatam muitas vezes que não se atentam às recomendações de manutenção, lavagem, vestir/despir, descarte e armazenagem dos EPI. Tais ações podem propagar ainda mais a contaminação do próprio profissional, dos que convivem com ele e do meio ambiente. A possível ineficiência da impermeabilidade e vedação dos EPI também precisa ser levada em consideração, uma vez que pode possibilitar a penetração de agrotóxicos dentro dos equipamentos. Neste sentido, ainda são escassos os estudos que mostram a influencia destes materiais para evitar possíveis intoxicações (Meirelles, Veiga \& Duarte, 2016; Veiga \& Melo, 2016).

Segundo Magalhães e Caldas (2019), as principais vias de exposição dos trabalhadores foram cutâneas e respiratórias (87,2\% dos casos). A maioria (81,7\%), relatou não usar qualquer tipo de proteção individual (EPI) (73,0\% entre os agentes de vigilância ambiental e 78,7\% entre os agricultores). Entre os trabalhadores que usaram algum EPI (N=70), luvas e máscaras foram os mais utilizados $(32,8 \%)$, e apenas $1,4 \%$ relataram a utilização de EPI completo (bota, chapéu, avental ou roupa impermeável, luva, máscara e óculos). Em consonância, Araújo, Nogueira e Augusto (2000) observaram em sua pesquisa, realizada no Estado de Pernambuco, que 64\% dos entrevistados não utilizavam equipamentos de proteção individual no momento de aplicação de produtos agrícolas.

A intoxicação de trabalhadores rurais em consequência do uso de agrotóxicos é um problema de saúde pública, que se agrava ainda mais se levarmos em consideração a família desses produtores, que normalmente vivem em torno das plantações, expondo-se diariamente a estes produtos, favorecendo o desenvolvimento dos casos de intoxicações e doenças a longo prazo (Maia et al., 2018).

A exposição destes familiares geralmente se dá através de partículas contaminantes, que tanto se espalham no ambiente durante a aplicação, contaminando o ar, alimentos e água, sendo carregadas para dentro das casas através das roupas utilizadas no campo pelos trabalhadores. Ademais, estudos demonstram que muitos trabalhadores armazenam produtos agrícolas dentro de suas próprias casas, sendo que alguns, inclusive, preparam a aplicação nestes mesmos locais (Maia et al., 2018).

De acordo com Araujo, Nogueira e Augusto (2000), dos trabalhadores agrícolas de culturas de tomate questionados no agreste pernambucano, a maioria usualmente não observa a direção dos ventos no momento da aplicação do produto. Além disso, quanto a destinação das embalagens vaziados dos produtos, verificou-se que 37\% eram enterradas no próprio lote ou na área de sequeiro e 18,5\% eram armazenadas para posterior queima, enquanto $44,5 \%$ não tinham um destino estabelecido previamente. A maioria das embalagens $(54,4 \%)$ foi deixada no campo ou teve outro destino inadequado, como o depósito de lixo comum. Constatou-se que 1,9\% dos entrevistados mencionaram o reaproveitamento das embalagens. Quanto às lavagens dos equipamentos de aplicação, $57 \%$ mencionaram que foram realizadas no local de trabalho, não havendo qualquer referência ao método indicado de tríplice lavagem. As roupas de trabalho eram lavadas, em 75,2\% dos casos, no ambiente doméstico, enquanto 24,8\% revelaram lavá-las em açudes, cacimbas e rios. Essas ações ocasionam risco tanto para o trabalhador e sua família como para a população em geral e o meio ambiente.

Segundo a Organização Internacional do Trabalho (OIT), os riscos à saúde dos trabalhadores devem ser continuamente estudados e avaliados, a fim de se implantar medidas de prevenção e proteção, minimizando os riscos ao trabalhador, a população e ao meio ambiente. Estas ações são praticamente inexistentes no ambiente rural, principalmente quanto à utilização de agrotóxicos, onde pouco se sabe sobre as consequências à saúde do trabalhador e sua família. Ainda, não se tem números fidedignos de casos de intoxicados por esses produtos e os meios de proteção para minimização da exposição têm se demonstrado ineficientes, tornando-se impossível o controle e a prevenção de intoxicações ocupacionais por agrotóxicos (Oit, 2001; Meirelles, Veiga \& Duarte, 2016; Veiga \& Melo, 2016). 


\subsubsection{Exposição A Agrotóxicos E Câncer}

Schinasi e Leon (2014), relacionaram a incidência de linfoma não-Hodgkin (LNH) a 21 grupos químicos de pesticidas e 80 princípios ativos. Para Hohenadel et al. (2011), os riscos de desenvolvimento de LNH intensificam-se com o aumento do número de agrotóxicos a que foram expostos, independentemente de sua classe. Neste sentido, notou-se que o risco subiu para quase duas vezes entre os trabalhadores que relataram o uso no campo de cinco ou mais pesticidas potencialmente carcinogênicos. Ademais, o uso de glifosato parece aumentar em até $41 \%$ do risco de desenvolver linfoma não-Hodgkin em indivíduos a ele expostos (Zhang et al., 2019).

Outros tipos de cânceres são relacionados a exposição a agrotóxicos, conforme estudo realizado por Silva et al. (2016), envolvendo 59 trabalhadores rurais portadores de neoplasia internados em um hospital universitário no Estado do Rio Grande do Sul. Dentre as malignidades, destacam-se as do sistema digestivo, com 62,7\% de ocorrência. Neoplasias masculinas e femininas nos sistemas genitais ocupam o segundo lugar, com uma porcentagem de $15,2 \%$, seguida de câncer do sistema urinário (10,2\%), bem como de câncer respiratório e de mama, ambos com 8,5\% cada. Entre o total de respondentes, 27,1\% tinham metástase. Segundo os autores, $58 \%$ dos trabalhadores acometidos realizavam pulverização apenas manualmente e grande parcela não fazia uso de EPIs.

A Quadro 4 nos apresenta a relação entre diferentes ingredientes ativos de grande consumo no Brasil e sua possível atividade carcinogênica (INCA) (2019).

Quadro 4 - Classificação quanto a carcinogenicidade dos ingredientes ativos de grande consumo no Brasil com autorização da ANVISA.

\begin{tabular}{|c|c|c|c|}
\hline \multirow{2}{*}{ NOME } & \multicolumn{2}{|c|}{ CLASSIFICAÇÃO DA CARCINOGENICIDADE } & \multirow{2}{*}{$\begin{array}{l}\text { RELAÇÃO COM O } \\
\text { CÂNCER } \\
\end{array}$} \\
\hline & IARC & USEPA & \\
\hline $2,4-\mathrm{D}$ & $\begin{array}{l}\text { Grupo 2B: Possivelmente } \\
\text { carcinogênico para Humanos }\end{array}$ & - & $\begin{array}{l}\text { Pele, Cavidade nasal, } \\
\text { sinonasal, nasofaringe, } \\
\text { orofaringe, laringe }\end{array}$ \\
\hline ACEFATO & ND & $\begin{array}{l}\text { Possível carcinogênico para } \\
\text { humanos }\end{array}$ & $\begin{array}{l}\text { Leucemias, Linfomas não } \\
\text { Hodgkin, pâncreas }\end{array}$ \\
\hline ATRAZINA & $\begin{array}{c}\text { Grupo 3: Não é classificável } \\
\text { para carcinogenicidade em } \\
\text { humanos }\end{array}$ & - & Linfomas não Hodgkin \\
\hline CLORPIRIFÓS & ND & $\begin{array}{c}\text { Ausência de carcinogenicidade } \\
\text { para seres humanos. }\end{array}$ & $\begin{array}{c}\text { Leucemias, Linfomas não } \\
\text { Hodgkin, pâncreas }\end{array}$ \\
\hline DIAZINONA & $\begin{array}{c}\text { Grupo 2A: Provavelmente } \\
\text { carcinogênico para Humanos }\end{array}$ & - & $\begin{array}{l}\text { Leucemias, Linfomas não } \\
\text { Hodgkin, câncer de pulmão }\end{array}$ \\
\hline DIURON & ND & $\begin{array}{c}\text { Provavelmente carcinogênico } \\
\text { para Humanos }\end{array}$ & $\begin{array}{c}\text { Neoplasia (sem localização } \\
\text { definida) }\end{array}$ \\
\hline GLIFOSATO & $\begin{array}{l}\text { Grupo 2A: Provavelmente } \\
\text { carcinogênico para Humanos }\end{array}$ & - & Linfomas não Hodgkin \\
\hline MALATIONA & $\begin{array}{l}\text { Grupo 2A: Provavelmente } \\
\text { carcinogênico para Humanos }\end{array}$ & $\begin{array}{l}\text { Linfomas não Hodgkin, câncer } \\
\text { de próstata. }\end{array}$ & - \\
\hline MANCOZEBE & $\begin{array}{c}\text { Grupo 3: Não é classificável } \\
\text { para carcinogenicidade em } \\
\text { humanos }\end{array}$ & - & Linfomas não Hodgkin \\
\hline METOMIL & ND & $\begin{array}{l}\text { Ausência de carcinogenicidade } \\
\text { para seres humanos }\end{array}$ & - \\
\hline
\end{tabular}

Fonte: Instituto Nacional do Câncer (INCA) (2019).

\subsubsection{Exposição a agrotóxicos e disfunção pulmonar}

A exposição a pesticidas também é associada a disfunção pulmonar. Dados de 19.704 agricultores do sexo masculino derivados do Estudo de Saúde Agrícola, realizado nos estados de Iowa e Carolina do Norte, EUA, foram utilizados para avaliar a associação entre a exposição a 48 agrotóxicos e a prevalência de asma alérgica e não alérgica de início adulto. Segundo o 
estudo, a alta exposição a pesticidas está associada a duplicação do risco de desenvolver asma alérgica e asma não alérgica de início adulto. Para asma alérgica, três herbicidas (2,4,5-TP, EPTC e paraquat), seis inseticidas (organoclorados: clordano, heptacloro e lindano e organofosforados: diazinon, paration e coumaphos), um fungicida (captan) e dois fumigantes (dibrometo de etileno e mistura 80/20 (tetracloreto de carbono e dissulfeto de carbono)), foram positivamente associados. Para asma não alérgica, um herbicida (óleo de petróleo) e três inseticidas (organoclorado: DDT; e organofosforados: forato e malatião) foram associados (Hoppin et al. 2009).

Ainda, neste sentido, um estudo realizado em áreas rurais nos arredores de vinhedos na França avaliou 281 crianças, com idade média de 7,5 anos, quanto a associação entre a exposição a pesticidas e a incidência de asma e rinite. Segundo os autores, do montante total, $22 \%$ tinham apresentado chiado pelo menos uma vez, 15,8\% já tinham sido diagnosticados com asma, $12 \%$ apresentavam asma no momento da pesquisa e 35\% tinham rinite alérgica. Ainda, encontrou-se associação entre a concentração de etilenotioureia, biomarcador urinário, para exposição a fungicidas ditiocarbamatos, (> 0,974ug / g creatinina) e sintomas de asma e rinite (OR = 3,56; IC 95\% 1,04-12,12) (Raherison et al, 2018).

\subsubsection{Exposição a agrotóxicos e desregulação endócrina}

Em relação aos efeitos endócrinos, a Comissão Europeia do Meio Ambiente identificou a atuação dos agrotóxicos como interferentes que podem danificar diretamente um órgão endócrino ou alterar sua função, além de poder interagir com receptores e alterar o metabolismo dos hormônios (ECE, 2019).

Ainda, inúmeros trabalhos demonstram associação da desregulação endócrina tireoidiana com a exposição à agrotóxicos. Um estudo desenvolvido na Romênia, analisou 108 trabalhadores de estufas e 28 pessoas em um grupo controle, para pesquisar a associação de diversos agrotóxicos (inseticidas, herbicidas e fungicidas) com a função tireoidiana. Foram encontrados aumento de TSH e redução de T4 livre nos trabalhadores de estufas quando comparados com o grupo controle. Em relação à prevalência de patologias tireoidianas, pode-se citar 12\% de hipotireoidismo e 10\% de elevação de anti-TPO no grupo dos trabalhadores (Simescu et al., 2014).

No mesmo sentido, inseticidas das classes organoclorados, organofosforados e piretróides foram estudados em 30 produtores agrícolas expostos a endosulfan, quinalphos, chlorpirifós, monocrotophos, lindano, parathion, forato e fenvalerato e comparados a um grupo controle de 20 pessoas residentes na mesma área para avaliar sua associação com alterações tireoidianas. A alteração mais significativa ( $\mathrm{P}<0,01$ ), foi o suprimento de T3 total no grupo de trabalhadores expostos. Apesar do TSH mais elevado no grupo exposto, este resultado não foi estatisticamente relevante (Zaidi et al., 2000).

Ainda, no Estado de Minnesota (EUA), foram selecionados 144 aplicadores de herbicidas e fungicidas do Red River Valley e 52 moradores urbanos como controle para um estudo de desregulação tireoidiana. Os aplicadores de agrotóxicos tiveram maior taxa de hipotireoidismo subclínico (TSH> 4,5 mU.L ${ }^{-1}$ ) em comparação com a população geral (3,4\% vs. $1 \%$ ). Alterações nos níveis de TSH foram associadas a exposição a fungicida (Garry, 2005).

\subsubsection{Exposição a agrotóxicos e parkinson}

Pesticidas também podem estar relacionados a disfunção mitocondrial e o estresse oxidativo, com mecanismos fisiopatológicos relacionados a doença de Parkinson em humanos. Quanto aos produtos agrotóxicos que agiram como estressores oxidativos, destaca-se o paraquat, enquanto dentre os produtos inibidores do complexo I mitocondrial, destaca-se a rotenona. Os participantes com a doença tinham 2,5 vezes mais probabilidade de terem utilizado na aplicação de culturas um dos produtos supracitados. Estes resultados podem ter grandes implicações a saúde, considerando o uso disseminado desses pesticidas. O paraquat continua sendo um dos herbicidas mais utilizados em todo o mundo, enquanto a rotenona foi usada de forma onipresente 
até ser proibido na União Européia e ter seu uso voluntariamente interrompido nos Estados Unidos, no ano de 2007 (Tanner et al., 2011).

\subsubsection{Intoxicação Não Ocupacional}

Segundo dados do SINAN (2020), dos 46.992 casos de intoxicação por Agrotóxicos Agrícolas notificados no sistema de informação, do ano de 2010 a 2020, no Brasil, 52,34\% não são resultados de exposição ocupacional. Destes, 8,55\% das intoxicações são decorrentes de exposição ambiental ou ingestão de alimento.

Quase a totalidade dos trabalhos que relacionam a exposição a agrotóxicos aos danos crônicos a saúde, concentram-se em trabalhadores rurais, vez que estão mais expostos a tais produtos, como já citado acima. Porém, os efeitos do uso exacerbado de agrotóxicos sobre a saúde não dizem respeito apenas a estes, mas sim à população em geral. Um estudo realizado em Lucas do Rio Verde/MT demonstrou que apesar de os níveis de organoclorados serem maiores na população rural, também foram encontrados, de forma significativa, no sangue e urina de moradores da zona urbana (Moreira et al., 2010).

\subsubsection{Exposição em gestantes e lactente}

Os agrotóxicos são considerados uma grave ameaça a saúde da população como um todo e não apenas aos trabalhadores rurais. Por estarem onipresentes no ambiente, expõem toda a população a uma grande variedade de produtos químicos, do período pré-concepcional até o fim da vida. Alguns são considerados muito persistentes no ambiente, resistindo à degradação ambiental e acumulando-se no tecido adiposo de todos os seres vivos, inclusive humanos, representando perigo a longo prazo (WHO, 2008).

Sabe-se que antes mesmo do nascimento o ser humano já está exposto aos pesticidas agrícola, pois estes produtos químicos são capazes de atravessar a barreira placentária. Whyatt e Barr (2001) detectaram metabólitos de organofosfatos no mecônio de vinte recém-nascidos analisados no Hospital Presbiteriano de Nova York, nos Estados Unidos da América. Segundo eles, o mecônio representa o conteúdo intestinal do bebê, que entre os constituintes estão células, líquido amniótico, lipídios e proteína. Através do mecônio pode-se identificar compostos aos quais o feto foi exposto durante a gestação, pois começa a se acumular na $16^{\mathrm{a}}$ semana de gravidez, sendo então eliminado após o parto.

Em 2010, um estudo realizado no leite materno de mulheres residentes na cidade de Lucas do Rio Verde, no estado do Mato Grosso, detectou a presença de resíduos de dez substâncias agrotóxicas nas amostras avaliadas. Nele, 100\% das amostras apresentaram contaminação por p,p'- DDE, 44\% por $\beta$-endossulfam e 13\% por p,p'-DDT. As demais substâncias analisadas foram encontradas abaixo do limite de quantificação do método. Deltametrina foi detectada em $37 \%$ das amostras, aldrim e $\alpha$ endossulfam, ambos em 32\%, $\alpha-\mathrm{HCH}$ em $18 \%$, trifluralina em $11 \%$ e lindano em $6 \%$. Dentre as nutrizes, menos da metade relataram já ter residido na zona rural e apenas $29 \%$ já haviam trabalhado ou trabalham em lavoura, sendo que apenas uma trabalhava em contato direto com agrotóxico, demonstrando que estes químicos ultrapassam os limites rurais, atingindo toda a população regional (Palma, 2011).

\subsection{Exposição a agrotóxicos e danos ao recém-nascido}

Verifica-se que os agrotóxicos são considerados agentes teratogênicos, que trazem consequências ao desenvolvimento e saúde dos recém-nascidos quando expostos intrauterinamente. Kuang et al. (2020) e Longnecker et al. (2001), em seu estudo, identificaram como principais consequências danos nos sistemas imunológico e neurológico, além de retardo no desenvolvimento e crescimento. Além disso, a ocorrência de anencefalia, espinha bífida, fenda labial com ou sem fenda palatina ou apenas fenda palatina (Lotufo, 2019; Yang et al., 2014), defeitos congênitos cardíacos em geral, dentre eles, a comunicação interventricular perimembranosa, defeito do septo atrioventricular e a coarctação da aorta, (Snijder, et al., 2012), bem como comprometimento neurocognitivos (Kim et al., 2015; Luo et al., 2017) e ocorrência de câncer infantil (Kuang et al., 2020), todos 
vinculados à exposição agrotóxica intrauterina. Salienta-se que bebês que apresentaram defeitos congênitos possuíam sete vezes mais probabilidade de terem nascido de mulheres expostas a produtos químicos (Heeren, Tyler \& Mandeya, 2003).

Em estudo realizado nas células ovarianas de hamsters, foram testados 200 pesticidas, classificados em nove grupos: organoclorados, éteres difenílicos, organofosforados, piretróides, carbamatos, amidas ácidas, triazinas, ureias e outros. Estes foram testados quanto ao agonismo e antagonismo a dois subtipos de receptores de estrogênio humano, o hER $\alpha$ e o hER $\beta$, e um receptor andrógeno humano (hAR). O trabalho revelou uma grande gama de pesticidas com potencial estrogênico e /ou antiandrogênico, via receptores de estrogénio e/ou receptores andrógeno. Dos testados, 34 pesticidas possuíam tanto atividades estrogênicas quanto antiandrogênicas, indicando efeitos pleiotrópicos em hER e hAR. Dos 200 pesticidas testados, 47 demonstraram atividades no hER $\alpha$ e $33 \mathrm{hER} \beta$. Dentre eles, 29 pesticidas tiveram atividade agonista em ambos receptores de estrogênio, havendo predominância do efeito em hER $\beta$ do que $\mathrm{hER} \alpha$ nos inseticidas organoclorados hexacloreto de $\beta$-benzeno (BHC), $\delta$-BHC e no inseticida carbamato metiocarbe. Efeitos antagonistas fracos foram demonstrados em cinco produtos em relação a $\mathrm{hER} \alpha$ e dois em hER $\beta$. Apesar de nenhum dos pesticidas testados apresentar atividade androgênica mediada por hAR, 66 de 200 pesticidas exibiram atividade inibitória contra a atividade transicional induzida pela $5 \alpha$-dihidrotestosterona. Destacamse as atividades antiandrogênicas de dois herbicidas do grupo éter difenílico, clornitrofena e clometoxifena, que foram superiores aos da vinclozolina e p, p'-diclorodifenil dicloroetileno, antagonistas conhecidos da via receptores androgênicos (Kojima et al., 2004).

Visto que sistema endócrino é fundamental para o desenvolvimento intrauterino embrionário e fetal; reprodução; crescimento e envelhecimento; maturação sexual; capacidade cognitiva e da memoria; libido; controle pressórico; metabolismo hidroeletrolítico e energético; e imunidade; sua desregulação traz consequências graves como doenças cardiovasculares; osteoporose; obesidade; diversos tipos de câncer, a destacar mama, útero e próstata; dificuldade de aprendizagem e de memória; e diabetes (Alves et al., 2007; Fonseca, 2019).

A desregulação endócrina pode ser também responsável por desenvolvimento sexual anormal, tendo como consequência telarca, pubarca, menarca e puberdade precoce, atraso puberal, ginecomastia, malformações reprodutivas, diminuição da qualidade do sêmen e endometriose, o que contribuem com a infertilidade. Durante a gestação, alterações endócrinas podem estar relacionadas a aborto espontâneo, parto prematuro e alterações no neurodesnvolvimento fetal (Alves et al., 2007; Fonseca, 2019).

\subsubsection{Exposição por ingestão de alimento}

A alimentação é considerada a principal fonte de exposição dos seres humanos aos agrotóxicos (Oliveira, 2016). Segundo o Programa de Análise de Resíduos de Agrotóxicos em Alimentos (PARA), mais da metade dos cereais, leguminosos, frutas e hortaliças consumidos pela população brasileira está contaminado por agrotóxicos. No estudo desenvolvido pelo programa, 19,7\% desses alimentos apresentaram resíduos de agrotóxicos não autorizados e/ou ultrapassaram os limites máximos de resíduos (LMRs) considerados aceitáveis pela ANVISA (ANVISA, 2016).

Neste mesmo estudo, 37,4\% das amostras apresentaram resíduos de mais de um agrotóxico simultaneamente, o que pode potencializar os efeitos tóxicos do produto e, consequentemente, os efeitos adversos à saúde (ANVISA, 2016).

No relatório do Programa de Análise de Resíduos de Agrotóxicos em Alimentos (PARA), no período de 2017 a 2018 , 28\% (1.290) das amostras analisadas apresentaram resíduos com concentrações iguais ou inferiores ao Limite Máximo de Resíduos (LMR), estabelecido pela Anvisa. Foram consideradas insatisfatórias 1.072 amostras (23\%) em relação à conformidade com o LMR (ANVISA, 2019). Vale ressaltar que mesmo abaixo do Limite Máximo de Resíduos esses valores devem ser considerados, já que a população se encontra exposta às diversas classes destes defensivos durante toda a vida, através de diversas 
fontes (Kuang et al., 2020). Na Quadro 5, encontram-se os alimentos avaliados no programa supracitado e os principais agrotóxicos destacados.

Quadro 5 - Análise de Resíduos de Agrotóxicos em Alimentos do Brasil.

\begin{tabular}{|c|c|c|c|c|c|c|}
\hline Alimento & $\begin{array}{l}\text { Porcentagem de } \\
\text { aquisição per } \\
\text { capita diária }\end{array}$ & $\begin{array}{l}\text { Amostras com } \\
\text { resíduos de } \\
\text { agrotóxicos } \\
\text { em concentrações } \\
\leq \text { LMR }\end{array}$ & $\begin{array}{l}\text { Amostras com } \\
\text { resíduos dos } \\
\text { agrotóxicos } \\
\text { em concentrações } \\
>\text { LMR/ } \\
\text { Agrotóxico mais } \\
\text { detectados nessa } \\
\text { situação } \\
\end{array}$ & $\begin{array}{l}\text { Quantidade de } \\
\text { agrotóxicos } \\
\text { detectados }\end{array}$ & $\begin{array}{l}\text { Principais } \\
\text { agrotóxicos } \\
\text { detectados }\end{array}$ & $\begin{array}{l}\text { Amostras com resíduos } \\
\text { de agrotóxicos não } \\
\text { autorizados para uso na } \\
\text { cultura / Agrotóxicos } \\
\text { mais detectadas nesta } \\
\text { situação }\end{array}$ \\
\hline Arroz & $16,65 \%$ & $28,6 \%$ & $\begin{array}{c}2,4 \% \\
\text { Piraclostrobina }\end{array}$ & 23 & $\begin{array}{c}\text { Tebuconazol } \\
\text { Triciclazol } \\
\text { Glifosato }\end{array}$ & $\begin{array}{c}2,1 \% \\
\text { Captana } \\
\text { Clotianidina } \\
\text { Fenpropatrina }\end{array}$ \\
\hline Abacaxi & $0,93 \%$ & $41,5 \%$ & $\begin{array}{l}8 \% \\
\text { Carbendazim } \\
\text { Etefom } \\
\text { Imidacloprido }\end{array}$ & 28 & $\begin{array}{l}\text { Carbendazim } \\
\text { Etefom } \\
\text { Imidacloprido }\end{array}$ & $\begin{array}{l}5,2 \% \\
\text { Azoxistrobina } \\
\text { Ciromazina } \\
\text { Diflubenzurom } \\
\text { Epoxiconazol } \\
\text { Imazalil } \\
\end{array}$ \\
\hline Goiaba & $0,31 \%$ & $10,2 \%$ & $\begin{array}{l}\qquad, 4 \% \\
\text { Imidacloprido } \\
\text { Tebuconazol } \\
\text { Ciproconazol }\end{array}$ & 43 & $\begin{array}{l}\text { Imidacloprido } \\
\text { Tebuconazol } \\
\text { Azoxistrobina }\end{array}$ & $\begin{array}{c}40,6 \% \\
\text { Cipermetrina } \\
\text { Ditiocarbamatos } \\
\text { Carbendazim } \\
\text { Lambda-Cialotrina } \\
\text { Acefato } \\
\end{array}$ \\
\hline Laranja & Não Informado & $45,3 \%$ & $\begin{array}{l}1,3 \% \\
\text { Formetano }\end{array}$ & 47 & $\begin{array}{c}\text { Imidacloprido } \\
\text { Piraclostrobina } \\
\text { Tebuconazol }\end{array}$ & $\begin{array}{c}12,5 \% \\
\text { Carbofurano } \\
\text { 2,4-D } \\
\text { Mepiquate } \\
\end{array}$ \\
\hline Manga & $0,61 \%$ & $29 \%$ & $\begin{array}{l}\quad 9 \% \\
\text { Formetanato }\end{array}$ & 33 & $\begin{array}{c}\text { Carbendazim } \\
\text { Ditiocarbamatos } \\
\text { Tebuconazol }\end{array}$ & $\begin{array}{l}\text { 9\% } \\
\text { Ometoato } \\
\text { Glifosato } \\
\text { Acefato }\end{array}$ \\
\hline Uva & $0,54 \%$ & $47 \%$ & $\begin{array}{c}15,4 \% \\
\text { Etefom } \\
\text { Clotianidina } \\
\text { Bifentrina }\end{array}$ & 66 & $\begin{array}{c}\text { Etefom } \\
\text { Difenoconazol } \\
\text { Imidacloprido }\end{array}$ & $\begin{array}{c}15 \% \\
\text { Propargito } \\
\text { Hexitiazoxi } \\
\text { Fenpiroximato } \\
\text { Acefato }\end{array}$ \\
\hline Alface & $0,57 \%$ & $33 \%$ & $\begin{array}{c}11 \% \\
\text { Imidacloprido } \\
\text { Cipermetrina } \\
\text { Pencicurom }\end{array}$ & 51 & $\begin{array}{l}\text { Imidacloprido } \\
\text { Difenoconazol } \\
\text { Ditiocarbamatos }\end{array}$ & $\begin{array}{c}17 \% \\
\text { Acefato } \\
\text { Clorfenapir } \\
\text { Carbendazim }\end{array}$ \\
\hline Chuchu & $0,50 \%$ & $5 \%$ & $0 \%$ & 11 & $\begin{array}{c}\text { Acefato } \\
\text { Flutriafol } \\
\text { Tebuconazol }\end{array}$ & $\begin{array}{c}9 \% \\
\text { Acefato } \\
\text { Dimetoato } \\
\text { Carbendazim }\end{array}$ \\
\hline Pimentão & $0,25 \%$ & $16 \%$ & \begin{tabular}{l}
\multicolumn{1}{c}{$24 \%$} \\
Cipermetrina \\
Deltametrina \\
Carbendazim \\
\end{tabular} & 69 & $\begin{array}{c}\text { Imidacloprido } \\
\text { Ditiocarbamatos } \\
\text { Carbendazim }\end{array}$ & $\begin{array}{c}80,6 \% \\
\text { Acefato } \\
\text { Metomil } \\
\text { Clorpirifós }\end{array}$ \\
\hline Tomate & $3,78 \%$ & $53 \%$ & $\begin{array}{c}2,5 \% \\
\text { Bifentrina } \\
\text { Ciflutrina } \\
\text { Lambda-Cialotrina }\end{array}$ & 45 & $\begin{array}{l}\text { Imidacloprido } \\
\text { Fenpropatrina } \\
\text { Carbendazim }\end{array}$ & $\begin{array}{l}33,5 \% \\
\text { Acefato } \\
\text { Clorpirifós } \\
\text { Fipronil }\end{array}$ \\
\hline Alho & $0,33 \%$ & $6 \%$ & $\begin{array}{c}0,3 \% \\
\text { Azoxistrobina }\end{array}$ & 27 & $\begin{array}{l}\text { Tebuconazol } \\
\text { Imidacloprido }\end{array}$ & $\begin{array}{c}4,4 \% \\
\text { Propamocarbe } \\
\text { Ciromazina }\end{array}$ \\
\hline
\end{tabular}




\begin{tabular}{|c|c|c|c|c|c|c|}
\hline Batata-doce & $0,40 \%$ & $0 \%$ & $0 \%$ & 16 & $\begin{array}{c}\text { Captana } \\
\text { Ciromazina }\end{array}$ & $\begin{array}{c}9 \% \\
\text { Captana } \\
\text { Ciromazina } \\
\end{array}$ \\
\hline Beterraba & $0,30 \%$ & $19 \%$ & $\begin{array}{c}5,3 \% \\
\text { Ditiocarbamatos }\end{array}$ & 21 & $\begin{array}{c}\text { Ditiocarbamatos } \\
\text { Tebuconazol } \\
\text { Difenoconazol }\end{array}$ & $\begin{array}{c}10,3 \% \\
\text { Clorpirifós } \\
\text { Pendimetalina } \\
\text { Acefato } \\
\text { Protiofós }\end{array}$ \\
\hline Cenoura & $0,98 \%$ & $51 \%$ & $\begin{array}{c}0,8 \% \\
\text { Triflurarina } \\
\text { Tetraconazol }\end{array}$ & 30 & $\begin{array}{c}\text { Procimidona } \\
\text { Piraclostrobina } \\
\text { Tebuconazol } \\
\end{array}$ & $\begin{array}{c}39,3 \% \\
\text { Clorpirifós } \\
\text { Acefato } \\
\text { Flutriafol }\end{array}$ \\
\hline
\end{tabular}

Fonte: Programa de Análise de Resíduos de Agrotóxicos em Alimentos - PARA (2019).

No estado do Paraná, segundo análise do PARA-PR, 18,8\% das amostras de alimentos analisados mostraram-se insatisfatórias, destacando-se morango, pimentão, uva e cenoura em que $72,22 \%, 56,52 \%, 50 \%$ e $50 \%$ das amostras encontravam-se irregulares, respectivamente (Parana,2013).

Diversos estudos demonstram a presença de resíduos agrotóxicos em verduras, legumes e frutas. Faria et al. (2009) analisaram, em seu trabalho, 55 amostras de polpa de morango industrializadas. Destas, 52 (95\%) revelaram resíduos de agrotóxicos, sendo que 27 (49\%) apresentaram produtos não autorizados, enquanto 35 (64\%) continham, na mesma amostra, quatro ou mais princípios ativos. Assim, encontrou-se até dez tipos de resíduos na mesma espécime, sendo que, dentre estes, seis não eram sequer autorizados.

Já Chu et al. (2019) investigaram a presença de 26 pesticidas em 299 pimentões de Shandong, China. Deste total, foram detectados 25 defensivos em 86 amostras, sendo que 7,36\% continham resíduos de mais de um agrotóxico.

Xu et al. (2018) coletaram 2.169 amostras de 12 vegetais típicos de províncias da China. Destas, 908 amostras (41,9\%) continham pelo menos um pesticida. Dos vegetais testados, o aipo teve a maior incidência $(88,4 \%)$, seguido do feijão-caupi (71,4\%) e pak-choi $(60,8 \%)$, um tipo de couve chinesa. Do total, $3,6 \%$ das amostras continham resíduos de três ou mais pesticidas.

Além das frutas, legumes e hortaliças supracitados, alimentos de origem animal, como carne, leite e ovos, também podem ser fontes de contaminação ao homem. A presença de agrotóxicos se dá, principalmente, pela utilização de defensivos durante o cultivo de produtos agrícolas utilizados para produção de rações e forragens, bem como pela presença de resíduos agrotóxicos na água e na pastagem e utilização de pesticidas no tratamento de parasitoses, que, quando não respeitados prazos de carência específicos, geram resíduos nos alimentos produzidos (Oliveira, 2016).

Em geral, os agrotóxicos possuem alta solubilidade a lipídios, concentrando-se em tecidos com maior teor de gordura, tais como tecido adiposo, cérebro, fígado e rim. Essas substâncias também se depositam com frequência nos músculos do animal (Mello \& Silveira, 2012; Oliveira, 2016).

Alimentos de origem animal também apresentam presença de resíduos de defensivos agrícolas. Oliveira (2016), identificou a presença de 22 agrotóxicos em 347 das 827 amostras de leite cru refrigerado, analisadas no estado de Minas Gerais. Destas, 218 amostras apresentaram resíduos de agrotóxicos acima dos limites permitidos pela legislação brasileira.

Já Ahamad, Salem e Estaitieh (2010), em seu trabalho realizado na Jordânia, encontraram pesticidas organoclorados em 28\% dos ovos examinados, $20 \%$ das carnes de frango e $49 \%$ das carnes de boi e cordeiro analisadas. Os organoclorados são extremamente lipossolúveis e de lenta degradação, podendo contaminar o homem através da cadeia alimentar, já que se acumular no meio ambiente e em seres vivos (Mello \& Silveira, 2012). 
Stefanelli et al. (2004) avaliaram 12 espécies de peixes, moluscos e crustáceos do Mar Adriático, na Itália, quanto a presença de pesticidas, a fim de verificar o nível de exposição da população italiana a estes produtos através dos frutos do mar. Este estudo demonstrou que todas as amostras continham diferentes níveis de resíduos de pesticida bifenilos policlorados (PCBs).

A presença de agrotóxicos nos alimentos decorre, principalmente, devido a sua ampla utilização, que ocorre, por muitas vezes, de forma incorreta. Este é um assunto que merece extrema atenção, pois pouco se sabe das consequências à saúde resultantes da exposição a estes compostos durante toda a vida, principalmente no que se diz respeito a reações cruzadas destes diversos compostos quimicamente diferentes, que podem acumular-se no organismo, potencializando os efeitos tóxicos do produto (Mello \& Silveira, 2012; Oliveira, 2016; ANVISA, 2016).

\subsubsection{Exposição o por consumo de água}

O uso exacerbado de agrotóxicos também contribui para a contaminação de reservatórios de água, rios, recursos hídricos e bacias fluviais, podendo afetar a fauna e flora aquática, bem como servir de fonte de exposição aos seres humanos, trazendo graves consequências a saúde pública (Lopes \& Albuquerque, 2018).

A maioria dos estudos de qualidade da água em bacias ou microbacias hirográficas e fontes destinadas ao abastecimento público no Brasil avaliam parâmetros físico-químicos, nutrientes, alcalinidade, contribuintes inorgânicos e avaliação microbiológica. Neste sentido, os estudos são muito escassos em relação aos agrotóxicos (Marques, 2005). Apesar disso, o número de trabalhos que pesquisam a contaminação da água por defensivos agrícolas vem crescendo a cada ano.

A contaminação da água pode se dar pela aplicação de defensivos direto na água, lixiviação do solo de áreas contaminadas, contaminação de águas subterrâneas por percolação do solo, liberação de efluentes industriais e despejo de matérias de descarte (Marques, 2005; Novais et al., 2021). Ações de cunho agrícola, que, muito embora não guardem relação direta ao agrotóxico em si, são capazes de reduzirem consideravelmente a contaminação, como terraceamento, curvas de nível, plantio direto e rotação de culturas, reduzindo, assim, a compactação e o escoamento superficial e também a erosão, que pode carregar pesticidas adsorvidos às partículas. Por isso, além do uso consciente acerca dos agrotóxicos, é importante conhecer e realizar corretamente os procedimentos agrícolas, a fim de reduzir poluição à pesticidas e, consequentemente, os riscos a saúde (Dellamatrice \& Monteiro, 2014).

Segundo Dellamatrice e Monteiro (2014), é baixa a concentração de pesticida dissolvidos na água, já que tais produtos são pouco hidrossolúveis, bem como pelos efeitos de diluição. Mesmo assim inúmeros trabalhos, infracitados, demonstram a presença destes produtos nas águas de todo país.

Marques (2005) estudou a qualidade de recursos hídricos na Bacia Hidrográfica do Rio Ribeira de Iguape, localizada na região sudeste do estado de São Paulo. Nele, das 76 amostras de água superficial analisadas, 29\% apresentaram resíduos agrotóxicos, destacando-se o carbofurano, que representa $21 \%$ deste total. As águas tratadas das estações de tratamento, operadas pela SABESP, também foram analisadas, apresentando resíduos de agrotóxicos em 19,7\% dos casos, com prevalência também do carbofurano, que é o pesticida mais vendido e aplicado na região de estudo.

Águas de poços artesianos também podem apresentar contaminação. Duas cidades do estado do Mato Grosso tiveram suas águas de poços artesianos, de córregos e rios analisadas quanto a presença de resíduos de agrotóxicos. Em Lucas do Rio Verde, $83 \%$ das amostras da água de poços artesianos, $81 \%$ das amostras de água de córregos e rios e $56 \%$ das amostras de água coletada da chuva, possuíam resíduos de agrotóxicos, sendo os defensivos mais frequentemente encontrados endosulfan, flutriafol e metolacloro. Já em Campo Verde, cerca de 50\% das amostras de água de poços coletadas apresentaram resíduos dos agrotóxicos. Ainda, nas 16 amostras de água de córregos e rios, coletadas entre novembro de 2007 a maio de 2008, em quatro pontos do município, foi possível identificar a presença de atrazina e seu produto de degradação DEA e endosulfan, em concentrações que variaram até $0,25 \mu \mathrm{g} / \mathrm{L}$. Também foi detectado, porém abaixo dos limites legais, clorpirifós, flutriafol, 
malation metolacloro e permetrina. As amostras de água de chuva demonstraram resíduos de DEA, atrazina, metil paration, malation, metolacloro, endosulfan, flutriafol e endosulfan S, em concentrações que variam de 0,11 a 75,43 $\mu \mathrm{g} / \mathrm{L}$ (Moreira et al., 2012)

Ademais, em um estudo realizado na água do lago urbano da cidade de Cascavel, estado do Paraná, utilizada no abastecimento público da cidade, conforme informação da Companhia de Saneamento do Paraná (SANEPAR), foi identificado e/ou quantificado resíduos de heptacloro epóxido, DDT, DDD e DDE em 29\%, 21\%, 13\% e 63\% das amostras analisadas, respectivamente (Cembranel et al., 2017).

Salienta-se que no ano de 2018, a Repórter Brasil, em conjunto com a Agência Pública e a organização suíça Public Eye, analisou dados do Ministério da Saúde, disponibilizado pelo Sistema de Informação de Vigilância da Qualidade da Água para Consumo Humano (Sisagua), referentes a testes na água de consumo da população dos municípios brasileiros, a fim verificar a presença de agrotóxicos (Aranha \& Rocha, 2019).

Mesmo obrigados por lei, 2.931 municípios brasileiros, do total de 5.570, não realizaram testes na água entre 2014 e 2017. Dentre os participantes, 2.300 municípios detectaram agrotóxicos na água dentro do período supracitado. Destes, 0,3\% ultrapassaram o limite legal brasileiro. Por outro lado, adotando-se os limites utilizados ela União Europeia, onde o controle destes compostos químicos são mais rigorosos, o percentual seria de 12\% (Aranha \& Rocha, 2019).

Ainda quanto a este estudo, nota-se que foram analisados 27 tipos de agrotóxicos, todos previsto na legislação pátria, sendo que 1.396 municípios detectaram todos os pesticidas testados. O efeito cruzado destes químicos é de grande preocupação para a saúde pública, vez que pode gerar ou aumentar efeitos nocivos a saúde. Sozinhos, 16 destes são considerados pela Anvisa como extremamente tóxicos. Ainda, em comparação, do total de 27 pesticidas encontrados na água dos brasileiros, 21 estão proibidos na União Europeia devido aos riscos que oferecem à saúde e ao meio ambiente (Brasil, 2018; Aranha \& Rocha, 2019).

Por fim, salienta-se que referido estudo demonstrou que a contaminação da água está aumentando a cada ano. Em 2014, 75\% dos testes detectaram agrotóxicos. Em 2015, o número chegou a 84\%, subindo para $88 \%$ em 2016 e a alarmantes 92\% em 2017 (Aranha \& Rocha, 2019).

\subsubsection{Exposição pelo ar}

$\mathrm{O}$ ar pode contribuir significativamente para a exposição humana aos agrotóxicos, especialmente pela sua capacidade de espalhar o produto por grandes distâncias, deixando de limitar a área contaminada ao espaço rural (Pignati, Machado \& Cabral, 2007).

Os pesticidas podem entrar na atmosfera através da pulverização, volatilização pós-aplicação e erosão eólica do solo tratado. Uma vez no ar, estes compostos podem ser redistribuídos, degradados, transportados e retornados à superfície da terra e água. Muitos pesticidas são poluentes orgânicos persistentes (POPs) devido a sua alta toxicidade, estabilidade, bioacumulação e potencial de transporte de longo alcance (LRT) (Yaoa et al., 2006).

As aplicações de agrotóxicos nas monoculturas são feitas através de pulverizações por tratores ou por aviões agrícolas, que tem como consequência a formação névoas de agrotóxicos. Tal ação atinge indiretamente os trabalhadores, o ar, o solo, a água, os moradores, os animais e outras plantas que estão no entorno das "áreas tratadas". Desta maneira, aumenta-se ainda mais a exposição da população e do meio ambiente, assim como a incidência de intoxicações (Pignati, Machado \& Cabral, 2007).

Um estudo realizado por em uma comunidade agrícola no Japão, detectou uma grande exposição por inalação de pesticidas em crianças de 1 a 6 anos de idade. Nele, foi avaliado a presença de organofosforados no ar interno e externo das casas e creches, após aplicações de pesticidas (Kawahara et al., 2005). Na Índia, um estudo similar, demonstrou presença de organoclorados, DDT e HCH, em amostras de ar e de chuva monitoradas de três áreas diferentes por dois anos (Pillai, 1986).

Foi descrita também a presença de pesticidas organoclorados e frações de enantiômeros de clordano nas amostras de ar interno 
coletadas em casas da região do cinturão de milho, localizada no nor-nordeste dos Estados Unidos (Leone et al., 2000). No Canadá, dados obtidos através da primeira parte da "Canadian Pesticide Air Sampling Campaign" - CPASC, realizada durante a primavera e verão do ano de 2003, demonstraram a identificação de 40 tipos de pesticidas no ar das diversas regiões agrícolas do Canadá, de acordo com os agrotóxicos utilizados nas atividades rurais de cada local (Yaoa et al., 2006).

\section{Conclusão}

A partir dos resultados de estudos apresentados nesta revisão de literatura, conclui-se que a utilização de agrotóxicos beneficia a produção agrícola e a economia mundial, no entanto, pode trazer danos impactantes a saúde da população. A exposição humana a estes produtos pode ocorrer através de alimentos, ar, água e alguns em contato direto, durante o desenvolvimento de suas atividades laborais, trazendo consequências graves a saúde. Tais consequências estão relacionadas a alterações imunológicas, genéticas, malformações congênitas, desenvolvimento de câncer, efeitos deletérios sobre os diversos sistemas, além de reações alérgicas e alterações comportamentais.

A caracterização epidemiológica destas intoxicações, no Brasil, não condiz com a realidade. Tal fato se deve a uma série de fatores, tais como: diagnósticos incorretos, subnotificação, dificuldade de acesso dos trabalhadores rurais às unidades de saúde e a inexistência de biomarcadores precoces e confiáveis. Além disso, as informações de saúde encontram-se dispersas em várias bases de dados, o que dificulta a percepção da real proporção do problema.

Desta forma, verifica-se a necessidade de realizar mais pesquisas para analisar as consequências da utilização de agrotóxicos a longo prazo à saúde e ao meio ambiente. É necessário também uma adequação das ações fiscalizadoras, a fim de diminuir os danos causados pelo o uso indevido dos produtos, bem como desenvolver ações preventivas e informativas a todos que utilizam-se de defensivos.

De maneira similar se faz importante a avaliação periódica do solo, água, ar e alimentos, para comprovação de qualidade, assim como, há necessidade de reavaliação das doses máximas permitidas, levando em consideração a múltipla exposição. O conhecimento acerca do assunto viabiliza o desenvolvimento destas ações de políticas públicas que podem minimizar os danos a população em geral, preservando desta forma a saúde humana e ambiental.

Sugerimos para trabalhos futuros a avaliação da população em geral exposta cronicamente a estes compostos químicos, através de testes de citotoxicidade e genotoxicidade.

\section{Referências}

ABNT NBR 9843, de 30 de setembro de 2019. Agrotóxicos e afins - Armazenamento. São Paulo: Associação Brasileira de Normas Técnicas.

ADAPAR. Agências de Defesa Agropecuária do Paraná. (2020). Pesquisa Agrotóxicos. http://www.adapar.pr.gov.br/modules/conteudo/ conteudo.php?conteudo $=387$.

Ahamad, R., Salem, N. M., \& Estaitieh, H. (2010). Occurrence of organochlorine pesticide residues in eggs, chicken and meat in Jordan. Chemosphere, 78 (6), $667-671$.

Alves, C., Flores, L. C., Cerqueira, T. S., \& Toralles, M. B. P. (2007). Exposição ambiental a interferentes endócrinos com atividade estrogênica e sua associação com distúrbios puberais em crianças. Cad. Saúde Pública, 23 (5), 1005-10014.

Anvisa. Agência Nacional de Vigilância Sanitária. (2012). Seminário volta a discutir mercado de agrotóxicos em 2012. http://portal.anvisa.gov.br/resultado-debusca?p_p_id=101\&p_p_lifecycle=0\&p_p_state=maximized\&p_p_mode=view\&p_p_col_id=column-

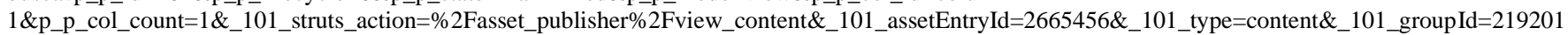
\&_101_urlTitle=seminario-volta-a-discutir-mercado-de-agrotoxicos-em-2012\&inheritRedirect=true.

Anvisa. Agência Nacional de Vigilância Sanitária. (2016). Programa de análise de resíduos de agrotóxicos em alimentos (PARA): Relatório das análises de amostras monitoradas no periodo de 2013 a 2015. http://portal.anvisa.gov.br/documents/219201/2782895/Relat\%C3\%B3rio+PARA/a6975824-74d6-4b8eacc3-bf6fdf03cad0?version=1.0. 
Anvisa. Agência Nacional de Vigilância Sanitária. (2019). Publicada reclassificação toxicológica de agrotóxicos. http://portal.anvisa.gov.br/noticias//asset_publisher/FXrpx9qY7FbU/content/publicada-reclassificacao-toxicologica-de-agrotoxicos-/219201/pop_up?_101_INSTANCE_F Xrpx9qY7Fb U_view Mode=print\&_101_INSTANCE_FXrpx9qY7FbU_languageId=pt_BR?

Anvisa. Agência Nacional de Vigilância Sanitária. (2019). Programa de análise de resíduos de agrotóxicos em alimentos (PARA): Relatório das análises de amostras monitoradas no período de 2017 a 2018. http://portal.anvisa.gov.br/documents/111215/0/Relat\%C3\%B3rio+\%E2\%80\%93+PARA+20172018_Final.pdf/e1d0c988-1e69-4054-9a31-70355109acc9.

Aranha, A. \& Rocha, L. (2019). "Coquetel” com 27 agrotóxicos foi achado na água de 1 em cada 4 municipios. https://apublica.org/2019/04/coquetel-com-27agrotoxicos-foi-achado-na-agua-de-1-em-cada-4-municipios-consulte-o-seu/.

Araújo, A. C. P., Nogueira, D. P., \& Augusto, L. G. S. (2000). Pesticide impact on health: a study of tomato cultivation. Rev Saúde Pública, 34 (3), $309-13$.

Batista, M. P. (2014). Avaliação citogenética e molecular de indivíduos ocupacionalmente expostos aos agrotóxicos (Dissertação Mestrado). Universidade Federal de Goiás, Goiânia, Brasil. https://repositorio.bc.ufg.br/tede/handle/tde/3014.

Bodin, J., Stene, L. C., \& Nygaard, U. C. (2015). Can Exposure to Environmental Chemicals Increase the Risk of Diabetes Type 1 Development? BioMed Research International, 2015, 19.

Brasil. Agência Nacional de Vigilância Sanitária. (2019a). Resolução Da Diretoria Colegiada - RDC No 296 , De 29 De Julho De 2019. http://portal.anvisa.gov.br/documents/10181/2858730/RDC_296_2019_.pdf/ca693bd5-e688-48e0-b072-0ece1dfca268.

Brasil. Decreto $n^{\circ} 4.074$, de 4 de janeiro de 2002. Publicado no Diário Oficial da União em 08/01/2002.

Brasil. Lei $n^{\circ} 7.802$, de 11 de julho de 1989. Publicada no Diário Oficial da União em 12/07/1989.

Brasil. Lei $n^{o}$ 12.651, de 25 de maio de 2012. http://www.planalto.gov.br/ccivil_03/_ato2011-2014/2012/lei/112651.htm.

Brasil. Ministério da Agricultura. (2019b). Diário Oficial traz registro de 42 defensivos agrícolas: objetivo é aumentar concorrência e baratear custo dos produtos. https://www.gov.br/agricultura/pt-br/assuntos/noticias/diario-oficial-traz-registro-de-42-defensivos-agricolas-objetivo-e-aumentar-concorrencia-ebaratear-custo-dos-produtos.

Brasil. Ministério da Saúde. Portaria nº3, de 16 de janeiro de 1992. http://bvsms.saude.gov.br/bvs/saudelegis/svs1/1992/prt0003_16_01_1992.html

Brasil. Ministério da Saúde. (2018). Relatório nacional de vigilancia em saúde de populações expostas a agrotóxicos. http://bvsms.saude.gov.br/bvs/publicacoes/relatorio_nacional_vigilancia_populacoes_expostas_agrotoxicos.pdf.

Brasil. Ministério do Trabalho. Norma Regulamentadora 31. Portaria MET n 86, de 03 de março de 2005. Publicada no D.O.U em 04/03/2005.

Brasil. Portaria $n^{o}$ 86, de 03 de março de 2005. Publicada no Diário Oficial da União, em 04/03/2005. https://www.mma.gov.br/estruturas/pnf/_arquivos/portaria_mte_86_05.pdf.

Bülow, A. E. (2008). Agrotóxicos e políticas públicas: práticas e contradições no município de novo Cabrais/RS (Dissertação Mestrado). Universidade Federal de Santa Maria, Santa Maria, Rio Grande do Sul, Brasil. http://w3.ufsm.br/ppggeo/files/dissertacoes_06-11/DissertacaBulow2008.pdf

Carneiro, F. F., Rigotto, R. M., Augusto, L. G. S., Friedrich, K., \& Búrigo, A. C. (2015). Dossiê ABRASCO: Um alerta sobre os impactos dos agrotóxicos na saúde. http://www4.planalto.gov.br/consea/publicacoes/seguranca-alimentar-e-nutricional/dossie-abrasco-um-alerta-sobre-os-impactos-dos-agrotoxicos-nasaude/11-dossie-abrasco-um-alerta-sobre-os-impactos-dos-agrotoxicos-na-saude.pdf.

Cembranel, A. S., Frigo, E. P., Sampaio, S. C., Mercante, E., Reis, R. R., \& Remor, M. B. (2017). Residue analysis of organochlorine and organophosphorus pesticides in urban lake sediments. Eng. Agríc, 37 (6), 1254-1267.

Chu, Z., Zhuang, M., Li, S., Xiao, P., Li, M., Liu, D., Zhou, J., Chen, J., \& Zhao, J. (2019). Residue levels and health risk of pesticide residues in bell pepper in Shandong. Food Additives \& Contaminants: Parte A, (11), 1-8.

Dellamatrice, P. M., \& Monteiro, R. T. R. (2014). Principais aspectos da poluição de rios brasileiros por pesticidas. Rev. bras. eng. agríc. Ambiente, 18 (12), 1296-1301.

ECE. European Commission Environment. (2019). Endocrine Disrupters. http://ec.europa.eu/environment/endocrine/documents/reports_en.htm.

Estrela, C. (2018). Metodologia Científica: Ciência, Ensino, Pesquisa. Porto Alegre: Editora Artes Médicas.

Farias, I. R. (2017). Analise da expressão dos genes de reparo da lesão de fita dupla do DNA de trabalhadores rurais expostos a agrotóxicos (Dissertação Mestrado). Departamento de Medicina Clínica, Faculdade de Medicina, Universidade Federal do Ceará, Fortaleza, Ceará, Brasil. http://www.repositorio.ufc.br/handle/riufc/25587

Faria, N. M. X., Facchini, L. A., Fassa, A. C. G., \& Tomasi, E. (2004). Trabalho rural e intoxicações por agrotóxicos. Cad. Saúde Pública, 20 (5), $1298-1308$.

Faria, V. H. F., Dias, B. M., Costa, M. C. M., Silva, V. R., Drummond, A. L., Franco, V. P., Cunha, M. R. R., Franklin, H. M. O. H., \& Peixoto, T. M. A. G. (2009). Avaliação de resíduos de agrotóxicos em polpas de morango industrializadas. Pesticidas: r. ecotoxicol. e meio ambiente, 19, 49-56.

Fonseca, I. F. A. (2019). Desregulação endócrina tireoidiana por agrotóxicos (Dissertação Mestrado) - Escola Nacional de Saúde Pública Sérgio Arouca, Fundação Oswaldo Cruz, Rio de Janeiro, Brasil. https://www.arca.fiocruz.br/handle/icict/39720

Garry, V. F. (2005). Biomarkers of thyroid function, genotoxicity and agricultural fungicide use. J Biochem Mol Toxicol., 19(3), 175-175. 
Heeren, G. A., Tyler, J., \& Mandeya, A. (2003). Agricultural chemical exposures and birth defects in the Eastern Cape Province, South Africa a case - control study. Environmental Health: A Global Access Science Source, 2(11), 1-8.

Hohenadel, K., Harris, S. A., Mclaughlin, J. R., Spinelli, J. J., Pahwa, P., Dosman, J. A., Demers, P. A., \& Blair, A. (2011). Exposure to Multiple Pesticides and Risk of Non-Hodgkin Lymphoma in Men from Six Canadian Provinces. Int. J. Environ. Res. Public Health, 8, 2320-2330.

Hoppin, J. A., Umbach, D. M., London, S. J., Henneberger, P. K., Kullman, G. J., Coble, J., Alavanja, M. C. R., Freeman, L, E. B., \& Sandler, D. P. (2009). Pesticide use and adult-onset asthma among male farmers in the Agricultural Health Study. Eur Respir J., 34(6), 1296-1303.

Ibama. Instituto Brasileiro Do Meio Ambiente E Dos Recursos Naturais Renováveis. (2018a). Relatórios de Comercialização de Agrotóxicos. Recuperado em http://www.ibama.gov.br/agrotoxicos/relatorios-de-comercializacao-de-agrotoxicos.

Ibama. Instituto Brasileiro Do Meio Ambiente E Dos Recursos Naturais Renováveis. (2018b). Consolidação de dados fornecidos pelas empresas registrantes de produtos técnicos, agrotóxicos e afins, conforme art. 41 do Decreto $4.074 / 2002$. https://www.ibama.gov.br/phocadownload/qualidadeambiental/relatorios/2017/Grafico-Consumo_agrotoxicos_2000-

2017.pdf?mc_cid=14e6d04801\&mc_eid=56bab855d0.

IBGE. Instituto Brasileiro de geografia e Estatística. (2018). Censo Agro 2017. https://agenciadenoticias.ibge.gov.br/agencia-sala-de-imprensa/2013-agenciade-noticias/releases/21905-censo-agro-2017-resultados-preliminares-mostram-queda-de-2-0-no-numero-de-estabelecimentos-e-alta-de-5-na-area-total.

INCA. Instituto Nacional de Câncer. (2019). Agrotóxico. https://www.inca.gov.br/exposicao-no-trabalho-e-no-ambiente/agrotoxicos.

Kawahara, J., Horikoshi, R., Yamaguchi, T., Kamugai, K., \& Yanagisawa, Y. (2005). Air pollution and young children's inhalation exposure to organophosphorus pesticide in an agricultural community in Japan. Environ Int., 31(8), 1123-1132.

Kim, S., Park, J., Kim, H., Lee, J. J., Choi, G., Choi, S., Kim, S., Kim, S. Y., Moon, H., Kim, S., \& Choi, K. (2015). Association between Several Persistent Organic Pollutants and Thyroid Hormone Levels in Cord Blood Serum and Bloodspot of the Newborn Infants of Korea. PLoS One., 10(5), 1-18.

Kojima, H., Katsura, E., Takeuchi,S., Niiyama, K., \& Kobayashi, K. (2004). Screening for Estrogen and Androgen Receptor Activities in 200 Pesticides by In Vitro Reporter Gene Assays Using Chinese Hamster Ovary Cells. Environ. Health Perspect., 112(5), p.524-531.

Kuang, L., Hou, Y., Huang, F., Hong, H., Sun, H., Deng, W., \& Lin, H. (2020). Pesticide residues in breast milk and the associated risk assessment: A review focused on China. Sci Total Environ, 727.

Leone, A. D., Ulrich, E. M., Bodnar, C. E., Falconer, R. L., \& Hites, R. A. (2000). Organochlorine pesticide concentrations and enantiomer fractions for chlordane in indoor air from the US cornbelt. Atmospheric Environment, 34(24), 4131-4138.

Longnecker, M. P., Klebanoff, M. A., Zhou, H., \& Brock, J. W. (2001). Association between maternal serum concentration of the DDT metabolite DDE and preterm and small-for-gestational-age babies at birth. The Lancet, 358(9276), 110-11.

Lopes, C. V. A. \& Albuquerque, G. S. C. (2018). Agrotóxicos e seus impactos na saúde humana e ambiental: uma revisão sistemática. Saúde debate, 42(117), 518-534.

Lotufo, M. N. (2019). Uso de agrotóxicos e ocorrência de fissuras labiopalatinas em recém-nascidos no estado de Mato Grosso (Dissertação Mestrado). Universidade de Cuiabá, Cuiabá, Mato Grosso, Brasil. https://repositorio.pgsskroton.com/handle/123456789/24141

Luo, D., Pu, Y., Tian, H., Wu, W., Sun, X., Zhou, T., Tao, Y., Yuan, J., Shen, X., Feng, Y., \& Mei, S. (2017). Association of in utero exposure to organochlorine pesticides with thyroid hormone levels in cord blood of newborns. Environmental Pollution, 231, 78-86.

Magalhães, A. F. A. \& Caldas, E. D. (2019). Occupational exposure and poisoning by chemical products in the Federal District Exposición e intoxicación ocupacional a productos químicos en el Distrito Federal. Rev Bras Enferm, 72(1), 36-44.

Maia, J. M. M., Lima, J. L., Rocha, T. J. M., Fonseca, S. A., Mousinho, K. C., \& Santos, A. F. (2018). Perfil de intoxicação dos agricultores por agrotóxicos em Alagoas Profile of intoxication of farmers by agrochemicals in Alagoas. Diversitas Journal., 3(2), 486-504.

Marques, M. N. (2005). Avaliação do impacto de agrotóxicos em áreas de proteção ambiental, pertencentes à Bacia Hidrográfica do Rio Ribeira de Iguape, São Paulo. Uma contribuição à análise crítica da legislação sobre o padrão de potabilidade. (Tese Doutorado). Instituto de pesquisas energéticas e nucleares, Universidade de São Paulo, São Paulo, São Paulo, Brasil. https://www.teses.usp.br/teses/disponiveis/85/85134/tde-04072006-131523/pt-br.php

Martins, M. K. S., Cerqueira, G. S., Sampaio, A. M. A., Lopes, A. A., \& Freitas, R. M. (2012). Exposição ocupacional aos agrotóxicos: um estudo transversal. Revinter, 5(3), 6-27.

Meirelles, L. A., Veiga, M. M., \& Duarte, F. (2016). A contaminação por agrotóxicos e o uso de EPI: análise de aspectos legais e de projeto. Laboreal, 12(2), 75-82.

Mello, I. N. K. \& Silveira, W. F. (2012). Resíduos de agrotóxicos em produtos de origem animal. Acta Veterinaria Brasilica, 6(2), 94-104.

Moreira, J. C., Peres, F., Simões, A. C., Pignati, W. A., Dores, E. C., Vieira, S. N., Strüssmann, C., \& Mott, T. (2012). Contaminação de águas superficiais e de chuva por agrotóxicos em uma região do estado do Mato Grosso. Ciência \& Saúde Coletiva, 17(6), 1557-1568.

Moreira, J.C., Peres, F., Pignati, W.A., \& Dores, E. F. G. C. (2010). Relatório de Pesquisa: Avaliação do risco à saúde humana decorrente do uso de agrotóxicos na agricultura e pecuária na Região Centro-Oeste. http://www.contag.org.br/imagens/f1656pignati---ufmt.pdf.

Neves, P. D. M. \& Bellini, M. (2013). Intoxicações por agrotóxicosna mesorregião norte central paranaense, Brasil - 2002 a 2011. Ciência \& Saúde Coletiva, $18(11), 3147-3156$. 
Novais, C. M., Queiroz, T. M., \& Seabra-Junior, S. (2021). Panorama da contaminação ambiental por agrotóxicos no estado do mato grosso: risco para o abastecimento urbano. Research, Society and Development, 10(1), 1-14.

OIT. Organização Internacional do Trabalho. (2001). Guidelines on occupational safety and health management systems (ILO-OSH 2001). https://www.ilo.org/global/publications/ilo-bookstore/order-online/books/WCMS_PUBL_9221116344_EN/lang--en/index.htm.

Oliveira, F. A. S. (2016). Resíduos de agrotóxicos em leite cru refrigerado: validação da ampliação do escopo de método por LC-MS/MS e análise multivariada de fatores que influenciam sua ocorrência no estado de Minas Gerais (Tese Doutorado). Escola de Veterinária, Universidade Federal de Minas Gerais, Belo Horizonte, Minas Gerais, Brasil. https://repositorio.ufmg.br/handle/1843/SMOC-AHYN48

OPAS/ OMS. Organização Pan-Americana de Saúde. (2018). OPAS/OMS destaca importância da atuação conjunta dos setores da saúde, agricultura e meio ambiente na regulamentação de agrotóxicos. https://www.paho.org/bra/index.php?option=com_content\&view=article\&id=5756:opas-oms-destacaimportancia-da-atuacao-conjunta-dos-setores-da-saude-agricultura-e-meio-ambiente-na-regulamentacao-de-agrotoxicos $\&$ Itemid=839.

Palma, D. C. A. (2011). Agrotóxicos em leite humano de mães residentes em Lucas do Rio Verde - MT (Dissertação Mestrado). Instituto de Saúde Coletiva, Universidade Federal de Mato Grosso, Cuiabá, Mato Grosso, Brasil.

Paraná. Decreto $n^{o}$ 3876, de 05 de agosto de 1994. Publicada no Diário Oficial do Estado do Paraná $\mathrm{n}^{\circ}$ 4321, em 05/08/1994. https://www.legislacao.pr.gov.br/legislacao/pesquisarAto.do?action=exibir\&codAto=25394\&indice=1\&totalRegistros=1\&dt=17.6.2020.9.27.0.301 .

Paraná. Decreto $n^{o}$ 6107, de 19 de janeiro de 2010. Publicada no Diário Oficial do Estado do Paraná $\mathrm{n}^{\circ}$ 8147, em 26/01/2010. https://www.legislacao.pr.gov.br/legislacao/pesquisarAto.do?action=exibir\&codAto=55097\&indice=1\&totalRegistros=2\&dt=17.6.2020.9.25.41.142.

Paraná. (2013). Programa Estadual de Análise de Resíduos de Agrotóxicos em Alimentos (PARA/PR): relatório preliminar. http://www.saude.pr.gov.br/arquivos/File/Resultados_para2013_preliminar.pdf.

Paraná. Lei $n^{o}$ 7827, de 29 de dezembro de 1983. Publicada no Diário Oficial do Estado do Paraná no 1691, em 30/12/1983. https://www.legislacao.pr.gov.br/legislacao/pesquisarAto.do?action=exibir\&codAto=9264\&indice=1\&totalRegistros=1\&dt=17.6.2020.9.27.44.981.

Paraná. Lei $n^{o}$ 17026, de 20 de dezembro de 2011. Publicada no Diário Oficial do Estado do Paraná n ${ }^{\circ}$ 8613, em 20/12/2011. https://www.legislacao.pr.gov.br/legislacao/pesquisarAto.do?action=exibir\&codAto=62723\&codTipoAto=\&tipoVisualizacao=alterado.

Paraná. Resolução no 57 de 22 de dezembro de 2014. Publicada no Diário Oficial do Estado do Paraná, em 23/12/2014. https://www.legisweb.com.br/legislacao/?id=279281.

Paraná. (2017). Plano de Vigilância e Atenção à Saúde de Populações Expostas aos Agrotóxicos do Estado do Paraná 2017 a 2019. http://www.saude.mppr.mp.br/arquivos/File/Programa_Agrotoxicos/Plano_Completo_2017.pdf.

Pereira, J. N. (2019). Assistência de enfermagem realizada a agricultores em uso de agrotóxico (Dissertação Mestrado). Programa de Pós-Graduação em Sistemas Agroindustriais, Universidade Federal de Campina Grande, Campus de Pombal, Paraíba, Brasil. http://dspace.sti.ufcg.edu.br:8080/xmlui/handle/riufcg/11236

Pignati, W. A., Machado, J. M. H., \& Cabral, J. F. (2007). Acidente rural ampliado: o caso das "chuvas" de agrotóxicos sobre a cidade de Lucas do Rio Verde - MT. Ciência \& Saúde Coletiva, 12(1), 105-114.

Pillai, M. K. K. (1986).Pesticide pollution of soil, water and air in Delhi area, India. Science of The Total Environment, 55, $321-327$.

Raherison, C., Baldi, I., Pouquet, M., Berteaud, E., Moesch, C., Bouvier, G., \& Canal-Raffin, M. (2018). Airborne pesticide exposure in vineyard rural areas and respiratory health in children: a pilot study. Environ Res., 169, 189-195.

Rebelo, F. M., Caldas, E. D., Heliodoro, V. O., \& Rebelo, R. M. (2011). Intoxicação por agrotóxicos no Distrito Federal, Brasil, de 2004 a 2007: análise da notificação ao Centro de Informação e Assistência Toxicológica. Ciência \& Saúde Coletiva, 16(8), 3493-3502.

Sanepar. Companhia de Saneamento do Paraná. (2019). Sanepar adota medidas para reforçar abastecimento em Cascavel. http://site.sanepar.com.br/noticias/estiagem-sanepar-toma-medidas-para-reforcar-abastecimento-em-cascavel.

Serra, L. S., Mendes, M. R. F. M., Soares, M. V. A., \& Monteiro, I. P. (2016). Revolução Verde: reflexões acerca da questão dos agrotóxicos. CEDS-UNDB, $1(4), 1-26$.

Schinasi, L. \& Leon, M. E. (2014). Non-hodgkin lymphoma and occupational exposure to agricultural pesticide chemical groups and active ingredients: a systematic review and meta-analysis. Int. J. Environ. Res. Public Health, 11(4), 4449-4527.

Spivey, A. (2011). Rotenone and Paraquat Linked to Parkinson's Disease: Human Exposure Study Supports Years of Animal Studies. Environ Health Perspect., $119(6), 258-9$.

Stachiw, R. T. S. (2019). Percepção de trabalhadores rurais quanto aos efeitos toxicológicos do uso e exposição a agrotóxicos. Nature and Conservation, 12(2), $11-18$.

Silva, A. C., Camponogara, S., Viero, C. M., Menegat, R. P., Dias, G. L., \& Miorin, J. D. (2016). Perfil socioeconômico de Trabalhadores Rurais portadores de neoplasia. J. res.: fundam. Care, 8(3), 4891-4897.

Silva, D. O., Ferreira, M. J. M., Silva, S. A., Santos, A. A., Hoffmann-Santos, H. D., \& Silva, A. M. C. (2019). Exposição aos agrotóxicos e intoxicações agudas em região de intensa produção agrícola em Mato Grosso, 2013. Epidemiol. Serv. Saúde, 28(3), 1-12.

Silva, J. M., Silva, E., Faria, H. P., \& Pinheiro, T. M. M. (2005) Agrotóxico e trabalho: uma combinação perigosa para a saúde do trabalhador rural. Ciencia \& Saúde Coletiva, 10(4), $891-903$. 
Sinan. Sistema de Informação de Agravos de Notificação. (2020). Intoxicação exógena. http://tabnet.datasus.gov.br/cgi/tabcgi.exe?sinannet/cnv/Intoxpr.def.

Simescu, M., Igna, C. P., Nicolaescu, E., Ion, I., Ion, A.C., Caragheorgheopol, A., Neagu, C., Negru, M., Pribu, M., Kochanska-Dziurowicz, A., \& StanjekCichoracka, A. (2014). Multiple pesticides exposure of greenhouse workers and thyroid parameters. Int. J. Sus. Dev. Plann., 9(1), 15-28.

Snijder, C. A., Vlot, I. J., Burdorf, A., Obermann-Borst, S. A., Helbing, W. A., Wildhagen, M. F., Steegers, E. A. P., \& Steegers-Theunissen, R. P. M. (2012). Congenital heart defects and parental occupational exposure to chemicals. Hum Reprod., 27(5), 1510-1507.

Solomon, C., Poole, J., Palmer, K. T., Peveler, R., \& Coggon, D. (2007). Acute symptoms following work with pesticides. Occupational Medicine, 57, 505511.

Stefanelli, P., Muccio, A. D., Ferrara, F., Barbini, D. A., Generali, T., Pelosi, P., Amendola, G., Vanni, F., Muccio, S., \& Ausili, A. (2004). Estimation of intake of organochlorine pesticides and chlorobiphenyls through edible fishes from the Italian Adriatic Sea during 1997. Food Control, 15 (1), 27-38.

Tanner, C. M., Kamel, F., Ross, G. W., Hoppin, J. A., Goldman, S. M., Korell, M., Marras, C., Bhudhikanok, G. S., Kasten, M., Chade, A. R., Comyns, K., Richards, M. B., Meng, C., Priestley, B., Fernandez, H. H., Cambi, F., Umbach, D. M., Blair, A., Sandler, D. P., \& Langston, J. W. (2011). Rotenone, Paraquat, and Parkinson's Disease. Environ Health Perspect., 119(6), 866-872.

Veiga, M. M. \& Melo, C. F. C. A. (2016). Análise da eficiência dos equipamentos de proteção aos agrotóxicos utilizados em saúde pública. Laboreal, 12(1), 53-62.

WHO. World Health Organization. (2008). Pesticides: Children's Health and the Environment. https://www.who.int/ceh/capacity/Pesticides.pdf.

Whyatt, R. M. \& Barr, D. B. (2001). Measurement of organophosphate metabolites in postpartum meconium as a potential biomarker of prenatal exposure. A validation study. Env Health Perspect, 109(4), 417-420.

Xu, X., Li, L., Huang, X., Lin, H., Liu, G., Xu, D., \& Jiang, J. (2018). Survey of four groups of cumulative pesticide residues in 12 vegetables in 15 provinces in china. Journal of Food Protection, 81(3), 377-385.

Yang, W., Carmichael, S. L., Roberts, E. M., Kegley, S. E., Padula, A. M., English, P. B., \& Shaw, G. M. (2014). Residential agricultural pesticide exposures and risk of neural tube defects and orofacial clefts among offspring in the San Joaquin Valley of California. Am J Epidemiol., 179(6), 740-748.

Yaoa, Y., Tudurib, L., Harnera, T., Blancharda, P., Don Waitec, D., Poissantd, L., Murphye, C., Belzerf, W., Aulagnierd, F., Lia, Y., \& Sverkog, E. (2006). Spatial and temporal distribution of pesticide air concentrations in Canadian agricultural regions. Atmospheric Environment, 40, 4339-435.

Zaidi, S. S., Bhatnagar, V. K., Gandhi, S. J., Shah, M. P., Kulkarni, P. K. \& Saiyed, H. N. (2000). Assessment of thyroid function in pesticide formulators. Human \& experimental toxicology, 19(9), 497-501.

Zhang, L., Ranaa, I., Shafferb, R. M., Taiolic, E., \& Sheppardb, L. (2019). Exposure to glyphosate-based herbicides and risk for non-Hodgkin lymphoma: A meta-analysis and supporting evidence. Mutation Research, 781, 186-206. 